\title{
Recognition of species groups of Naupactus Dejean (Coleoptera: Curculionidae) from Argentina and neighboring countries
}

\author{
María G del Río ${ }^{\text {Corresp., }} 1$, Analía A Lanteri ${ }^{\text {Corresp. } 1}$ \\ 1 División Entomología, Museo de La Plata, FCNyM, CONICET, Universidad Nacional de La Plata, La Plata, Buenos Aires, Argentina \\ Corresponding Authors: María G del Río, Analía A Lanteri \\ Email address: gdelrio@fcnym.unlp.edu.ar, alanteri@fcnym.unlp.edu.ar
}

Naupactus Dejean is the most diverse genus of the tribe Naupactini (Curculionidae: Entiminae), with more than 200 species occurring in South America, of which about 40 range in Argentina and neighboring countries. The Argentinean species treated herein were classified into nine groups associated with different biogeographic units: 1- the groups of Naupactus xanthographus, N. delicatulus and N. auricinctus are present in northeastern Argentina (Misiones province) and reach the highest species diversity in the Atlantic and Parana forests of Brazil; 2- the groups of Naupactus hirtellus, N.

cinereidorsum, $N$. rivulosus and $N$. tarsalis show the highest species diversity in the Chacoan biogeographic province and also occur in the Yungas, Espinal, Monte, Parana forest (Argentina) and Cerrado (Brazil); 3- the groups of Naupactus leucoloma and $N$. purpureoviolaceus have the highest species diversity in the Pampean biogeographic province, being also present in adjoining areas, mainly Chaco, Espinal, Monte and Parana forest. We provide descriptions, a dichotomous key, habitus photographs and line drawings of genitalia for the identification of the nine species groups, and a list of the Argentinean species from each group, together with their abbreviated synonymies, updated geographic distributions (including six new country records and several state/province records) and host plant associations. We discuss the characters that allow the separation of the species groups in a geographic distribution context, and provide information on species reassigned to genera other than Naupactus; among these, we transferred $N$. cephalotes (Hustache) to the tribe Tanymecini, genus Eurymetopellus, establishing the new combination $E$. cephalotes. 


\section{Recognition of species groups of Naupactus Dejean}

3 (Coleoptera: Curculionidae) from Argentina and

4 neighboring countries

5

6

7 María G. del Río, Analía A. Lanteri

8

Corresponding Author:

Analía Lanteri

Email address: alanteri@fcnym.unlp.edu.ar

María G. del Río

Email address: gdelrio@fcnym.unlp.edu.ar

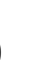

División Entomología, Museo de La Plata, FCNyM, Universidad Nacional de La Plata, CONICET, La Plata, Buenos Aires, Argentina

Paseo del Bosque s/n, La Plata, Buenos Aires, 1900, Argentina

Paseo del Bosque s/n, La Plata, Buenos Aires, 1900, Argentina 


\section{ABSTRACT}

36 Naupactus Dejean is the most diverse genus of the tribe Naupactini (Curculionidae: Entiminae), 37 with more than 200 species occurring in South America, of which about 40 range in Argentina

38

56

\section{INTRODUCTION} and neighboring countries. The Argentinean species treated herein were classified into nine groups associated with different biogeographic units: 1- the groups of Naupactus xanthographus, $N$. delicatulus and $N$. auricinctus are present in northeastern Argentina (Misiones province) and reach the highest species diversity in the Atlantic and Parana forests of Brazil; 2the groups of Naupactus hirtellus, $N$. cinereidorsum, $N$. rivulosus and $N$. tarsalis show the highest species diversity in the Chacoan biogeographic province and also occur in the Yungas, Espinal, Monte, Parana forest (Argentina) and Cerrado (Brazil); 3- the groups of Naupactus leucoloma and $N$. purpureoviolaceus have the highest species diversity in the Pampean biogeographic province, being also present in adjoining areas, mainly Chaco, Espinal, Monte and Parana forest. We provide descriptions, a dichotomous key, habitus photographs and line drawings of genitalia for the identification of the nine species groups, and a list of the Argentinean species from each group, together with their abbreviated synonymies, updated geographic distributions (including six new country records and several state/province records) and host plant associations. We discuss the characters that allow the separation of the species groups in a geographic distribution context, and provide information on species reassigned to genera other than Naupactus; among these, we transferred N. cephalotes (Hustache) to the tribe Tanymecini, genus Eurymetopellus, establishing the new combination E. cephalotes.

Naupactus Dejean is the most diverse genus of the tribe Naupactini (Curculionidae: Entiminae), with ca. 200 species occurring in South America (Wibmer \& O’Brien, 1986; Bordón, 1997) and five in Central America, which were previously classified in Alceis Billberg by O'Brien \& Wibmer (1982). However, the precise number is still uncertain because new species remain to be described while others should probably be synonymized (Lanteri \& del Río, 2017a). Hustache (1947) published the only comprehensive taxonomic work on Naupactus from Argentina and neighboring countries, which included a dichotomous key, descriptions of several species and new geographic records for taxa previously described by Boheman in Schoenherr (1833, 1840) and by himself (Hustache, 1923; Hustache, 1926; Hustache, 1938). Nonetheless, 
67 these contributions lack illustrations of habitus or external features of taxonomic value,

68 descriptions of genital characters, information on host plant associations and provide limited

69

70

71

72

73

74

75

76

77

78

79

80

81

82

83

84

85

86

87

88

89

90

91

92

93

94

95

96

97

98

geographic data. The checklist of Wibmer \& O'Brien (1986) included new synonymies proposed

by Kuschel and updated country records for several species. They reported 45 Argentinean

species, but this number was increased to 57 by Morrone (1999) as a result of transferring most

of the South American taxa previously classified in Pantomorus Schoenherr to Naupactus.

The earliest classification of the South American Naupactus into species groups was made by Lanteri \& Marvaldi (1995) and Lanteri \& del Río (2017a). They described and revised the $N$. leucoloma Boheman and N. xanthographus (Germar) species groups, which include some species of great economic importance due to the damage they cause to agriculture in Argentina and other countries worldwide (Buchanan, 1939; Elgueta, 1993; Guzmán, Lanteri \& Confalonieri, 2012; Lanteri et al., 2013). Moreover, they analyzed the phylogenetic placement of Naupactus within the tribe Naupactini (Lanteri \& del Río, 2017b; del Río et al., 2018) and proposed new synonymies for some species showing color variation, morphotypes and/or sexual dimorphism (del Río \& Lanteri, in press).

The main objectives of this paper are to recognize and describe the species groups of Naupactus distributed in Argentina and neighboring countries; to provide a dichotomous key for their identification; to illustrate the diagnostic features of these groups by habitus photographs and line drawings of genitalia; and to provide updated information on the synonymies, host plant associations and geographic distributions for all the Argentinean species included in these groups. The recognition of species groups is very useful to identify species belonging to highly diverse genera and helps to understand their evolution in a historical biogeographic context (del Río, Morrone \& Lanteri, 2015; del Río et al. 2018).

\section{MATERIALS \& METHODS}

This study is based on the examination of about 5,000 specimens deposited in the following entomological collections: American Museum of Natural History (New York, USA), Arizona State University Charles W. O’Brien Collection (Tempe, USA), Coleção Entomologica do Instituto Oswaldo Cruz (Rio de Janeiro; Brazil), Departamento de Zoologia da Universidade

7 Federal do Paraná (Curitiba, Brazil), Fundación e Instituto Miguel Lillo collection (San Miguel de Tucumán, Argentina), Museo de La Plata (La Plata, Argentina), Museu Nacional do Rio de 
99 Janeiro (Rio de Janeiro, Brazil), Museu de Zoologia da Universidade de São Paulo (São Paulo, 100 Brazil), Muséum National d'Histoire Naturelle (Paris, France), The Natural History Museum 101 (London, United Kingdom), United States National Museum (Washington DC, USA), and 102 Universidad de la República (Montevideo, Uruguay).

103 Dissections of female and male genitalia were made according to standard entomological 104 techniques (Lanteri \& O’Brien, 1990). Genital characters were drawn using a camera lucida 105 adapted to a Nikon SMZ800 stereoscopic microscope (Tokyo, Japan). An ocular micrometer 106 attached to this microscope was used to take measurements.

107 The biogeographical scheme used to describe the distributions of the Naupactini genera are in 108 agreement with that of del Río, Morrone \& Lanteri (2015), except for the Espinal (sensu Cabrera $109 \&$ Willink, 1973), which is here considered as separate from the Chacoan and Pampean 110 biogeographic provinces. In Argentina, the Espinal is a xerophilous forest dominated by 111 Prosopis L. that constitutes an arch between the latter biogeographic provinces.

112 The electronic version of this article in Portable Document Format (PDF) will represent a 113 published work according to the International Commission on Zoological Nomenclature (ICZN), 114 and hence the new names contained in the electronic version are effectively published under that 115 Code from the electronic edition alone. This published work and the nomenclatural acts it 116 contains have been registered in ZooBank, the online registration system for the ICZN. The 117 ZooBank LSIDs (Life Science Identifiers) can be resolved and the associated information viewed 118 through any standard web browser by appending the LSID to the prefix http://zoobank.org/. The 119 LSID for this publication is: urn:lsid:zoobank.org:pub:B9BB18E6-2ED8-4928-9FA54B5CB2027BDF. The online version of this work is archived and available from the following digital repositories: PeerJ, PubMed Central and CLOCKSS.

\section{RESULTS}

In the current contribution we recognized 37 species of Naupactus, which were assigned to nine species groups ranging in Argentina, Bolivia, southern Brazil, Paraguay and Uruguay. These groups are characterized by a particular combination of characters of the external morphology and genitalia, and occur in one or more biogeographic provinces of the Neotropical Region.

\section{Key to species groups and subgroups of Naupactus from Argentina}


130

131 1. Elytra with pair of tubercles at apex

132

N. xanthographus species group (Figs. 1A-B)...

133 1a. Elytra lacking pair of tubercles at apex.................................... 2

134 2. Humeri well-developed; base of elytra bisinuate. Pronotum usually subconical and smooth or slightly punctate. Metathoracic wings well-developed.

2a. Humeri usually reduced, if well-developed, elytral setae long and erect; base of elytra straight. Pronotum subcylindrical, usually granulose. Metathoracic wings reduced to absent. .7

139 3. Metatibial apex with broad, squamose corbel. Species usually more than $13 \mathrm{~mm}$ long. 4

141 3a. Metatibial apex lacking corbel or with very slender corbel. Species usually less than $13 \mathrm{~mm}$ 142 long...... 5

143 4. Antennae moderately robust; scape reaching to slightly exceeding hind margin of eye. Scaly 144 vestiture dull-colored and uniformly distributed, or arranged in stripes along pronotum and 145 elytra, leaving denuded areas. Disc of pronotum usually convex, with deep median groove. Intervals of elytra convex; punctures of striae usually broad

N. rivulosus species group (Figs. 1C-E)

4a. Antennae slender; scape exceeding anterior margin of pronotum. Scaly vestiture completely covering integument. Disc of pronotum flat or impressed; median groove linear to indistinct. Intervals of elytra usually flat; punctures of striae small.

5. Integument slightly sclerotized, covered with iridescent green, purple, or copper colored scales; elytral setae usually long and erect. Antennae slender, usually reddish; scape reaching to slightly exceeding hind margin of eye. Pronotum subcylindrical, punctuate or rugose, usually very convex in males. Disc of elytra flat to slightly convex, lower than pronotum in lateral view. Spermathecal duct spiraled. .N. auricinctus species group (Figs. 1H-I) 5a. Integument strongly sclerotized, uniformly covered with dull-colored scaly vestiture or with pair of yellow or green longitudinal stripes, leaving denuded areas; elytral setae short, recumbent. Antennae stout, black; scape not exceeding hind margin of eye. Pronotum usually 
160 subconical, smooth and flat. Disc of elytra convex, higher than pronotum in lateral view.

161 Spermathecal duct not spiraled 6

$1626 . \quad$ Scaly vestiture usually green, yellow or cream, arranged in stripes along pronotum and 163 elytra, leaving remaining parts of integument denuded. Lateral carinae of rostrum sharp,

164 165

166 167 168 169 170 171 172 173 174 denuded. Base of elytra usually strongly bisinuate; intervals slightly convex .N. tarsalis species group...(Figs. 2A-D)

6a. Scaly vestiture usually dull-colored, uniformly distributed or almost lacking. Lateral carinae of rostrum not sharp, squamose. Base of elytra slightly bisinuate; intervals usually flat ... ................. cinereidorsum species group (Figs. 2E-F)

7. Protibiae lacking row of denticles on inner edge. Metatibial apex with narrow, setose corbel. Pronotum almost smooth. Scaly vestiture iridescent green or grey; elytral setae of medium-length and suberect .......... hirtellus species group (Figs. 3A-B)

7a. Protibiae with row of denticles on inner edge. Metatibial apex usually lacking corbel (external edge thickened/in some species). Pronotum granulose. Scaly vestiture dull-colored or almost lacking, accompanied by long, suberect to erect elytral setae, or iridescent green, purple or copper colored, having short, recumbent elytral setae. .8 8. Scaly vestiture dull-colored, with characteristic lateral white stripes from apex of rostrum to apex of elytra, accompanied by long and erect elytral setae........

8a. Scaly vestiture completely lacking on dorsal surface, or iridescent green, purple, or copper colored, accompanied by short, recumbent elytral setae, or dull-colored, but without white stripes from apex of rostrum to apex of elytra.

\section{N. purpureoviolaceus species group (Figs. 3D-I)}

(1)

\section{Criteria for inclusion of Naupactus species recorded from Argentina}

The 37 species of Naupactus from Argentina under consideration show the combination of characters detailed in del Río et al. (2018). This species number is the result of the following taxonomic and nomenclatural decisions: 
190 1. Lanteri \& Marvaldi (1995) synonymized Graphognathus Buchanan with Naupactus, and 191 consequently the three species of "white-fringed beetles" assigned to Graphognathus in Wibmer 192 \& O’Brien (1986) were named N. leucoloma Boheman, N. minor (Buchanan) and N. peregrinus 193 (Buchanan).

194 2. Some species were recently transferred from Naupactus to other genera, e.g. N. carinirostris 195 (Hustache) and N. signatus (Blanchard) sensu Morrone (1999), to Parapantomorus Emden, and 196 to Symmathetes Schoenherr, respectively (del Río \& Lanteri, in press); N. sulphureoviridis 197 (Hustache), originally classified in Teratopactus Heller (del Río, Lanteri \& Guedes, 2006) and 198 later in Naupactus, was recently placed in the original genus (del Río \& Lanteri, in press); and $N$. 199 inermis Hustache was synonymized with Macrostylus (Mimographus) ocellatus Lanteri (del Río 200 \& Lanteri, in press) and transferred to Lanterius Alonso-Zarazaga \& Lyal, based on the results of 201 a cladistic analysis (del Río et al. 2018).

202 3. Lanteri \& del Río (2017a) described the new species $N$. marvaldiae for the N. xanthographus 203 species group, and del Río \& Lanteri (in press) established new synonymies for several species 204 showing color variation, sexual dimorphism or polymorphism, i.e., N. bridgesii G.R. Waterhouse 205 (senior syn. of N. angulithorax Hustache); N. auricinctus (senior syn. of N. ruficornis Boheman); 206 N. peregrinus (Buchanan) (senior syn. of N. brevicrinitus Hustache); N. condecoratus Boheman 207 (senior syn. of N. bosqi Hustache); and N. cyphoides (Heller) (senior syn. of N. calamuchitanensis 208 Hustache, N. viridinitens Hustache and N. viridulus Hustache).

209 4. Naupactus transversus Boheman and N. ambiguus Boheman were excluded from this paper 210 because they only occur in Brazil. The specimens misidentified as $N$. transversus in most 211 entomological collections probably belong to a new species (they were labeled as N. missionum 212 Kuschel in litteris at the MZSP) distributed in Argentina, Brazil and Paraguay; and the 213 specimens usually misidentified as N. ambiguus correspond to Pantomorus postfasciatus 214 (Hustache), which share the geographic range of the latter species, plus Uruguay.

215 5. We excluded several species transferred from Pantomorus to Naupactus by Morrone (1999) 216 because, in agreement with Wibmer \& O'Brien (1986), we consider that they should be better 217 classified in Pantomorus, at least until a comprehensive revision of the South American species 218 of this genus is made. These are: P. auripes Hustache, P. fulvus Hustache, P. prasinus Hustache, 219 P. similis Hustache, and P. ruizi (Brèthes), which are within the P. auripes species group 220 (Morrone \& Lanteri, 1991; Lanteri et al., 1991; Lanteri, 1995; Scataglini, Lanteri \& 
221 Confalonieri, 2005); P. viridisquamosus (Boheman) and P. obrieni Lanteri, within the $P$.

222 viridisquamosus species group (Lanteri \& Loiácono, 1990); the probably related P. humilis

223 Hustache and $P$. hirsuticeps Hustache; the highly modified $P$. luteipes Hustache, displaying ant

224 mimicry; $P$. bruneus Hustache from northwestern Argentina, which is probably close to $P$.

225 minutus Hustache and to P. minutellus Wibmer \& O’Brien from Bolivia and Peru, and allied to

226 Asymmathetes Wibmer \& O’Brien; P. postfasciatus (Hustache) originally described in

227 Asynonychus and frequently misidentified as Naupactus ambiguus Boheman (Lanteri, Guedes \&

228 Parra, 2002; Guedes, Lanteri \& Parra, 2005); and the controversial P. cinerosus (Boheman)

229 originally described in Naupactus and having six synonyms assigned to Pantomorus (Hustache,

230 1947; Wibmer \& O’Brien, 1986; Morrone, 1999; Lanteri, Marvaldi \& Suarez, 2002; Guedes,

231 Lanteri \& Parra, 2005).

232 6. We excluded the "fuller's rose weevil" Naupactus cervinus Boheman because of its 233 controversial taxonomic position (del Río et al. 2018). Indeed, it has been classified in 234 Asynonynchus Crotch (Hustache, 1947; Lanteri, 1986; Morrone, 1999), in Pantomorus 235 (Buchanan, 1939; O’Brien \& Wibmer, 1982; Wibmer \& O’Brien, 1986) and in Naupactus 236 (Alonso-Zarazaga \& Lyal, 1999). Asynonychus (type species A. godmani Crotch= N. cervinus 237 Boheman) was synonymized with Naupactus in Alonso-Zarazaga \& Lyal (1999), but we 238 consider that it should be treated either as a genus independent from Naupactus and Pantomorus, 239 or as a junior synonym of Alceis Billberg.

240 7. Asynonychus cephalotes Hustache, 1947, classified in Pantomorus by Wibmer \& O'Brien 241 (1986) and in Naupactus by Morrone (1999), it is not a Naupactini and meets definition of genus 242 Eurymetopellus Emden, therefore it is herein transferred to Tanymecini, genus Eurymetopellus, 243 thus establishing the new combination Eurymetopellus cephalotes (Hustache).

\section{Descriptions of groups of Naupactus from Argentina}

249 This group, which was revised by Lanteri \& del Rio (2017a), includes six species mainly 250 distributed in the Parana and Atlantic forests of Brazil. In Argentina, N. dissimilis Hustache, $N$. 251 navicularis Boheman and N. marvaldiae Lanteri \& del Río are restricted to Misiones province; 
$252 N$. dissimulator Boheman ranges from this province to Buenos Aires along the gallery forests of 253 the Parana river, reaching the southernmost distribution limit of the species group in the Parana 254 forest; and N. xanthographus (Germar) is the only species widely distributed in the Central and 255 Northern areas of the country and has also been introduced in Chile (Guzmán, Lanteri \& 256 Confalonieri, 2012). Naupactus mimicus Hustache is endemic to the Atlantic-Parana forests of 257 Brazil. Within the N. xanthographus species group, Lanteri \& del Río (2017a) recognized two 258 subgroups, one including $N$. xanthographus, $N$. dissimilis, $N$. navicularis and $N$. mimicus, and the 259 other $N$. dissimulator and N. marvaldiae.

260

261 Species Included:

262 1-Naupactus dissimilis Hustache, 1947

263 Geographic distribution. Northeastern Argentina (Misiones), Brazil (Paraná, Rio Grande do 264 Sul and Santa Catarina), Paraguay (Alto Paraná, Caaguazú and Itapúa) and Uruguay (Artigas) 265 (Lanteri \& del Río, 2017a).

266 Host plants. Coniza albida Willd. ex Sprengel (Asteraceae), Citrus maxima (Burm.) Merr. 267 (Rutaceae), Ilex paraguariensis Saint Hill. (Aquifoliaceae) and Zea mays L. (Poaceae) (Lanteri $268 \&$ del Río, 2017a).

269

270

2-Naupactus dissimulator Boheman, 1840 (= N. fallax Boheman, 1840)

271 Geographic distribution. Argentina (Buenos Aires, Corrientes, Misiones and Santa Fe), Bolivia 272 (Cochabamba), Southern Brazil (Paraná, Santa Catarina and Río Grande do Sul), Paraguay 273 (Itapúa) and Uruguay (Colonia, Maldonado, Montevideo and Paysandú) (Lanteri \& del Rio, 274 2017a).

275 Host plants. Ocotea punchella (Nees \& Mart.) Mez (Lauraceae), Citrus sinensis L. (Rutaceae), 276 Ilex paraguariensis Saint Hill (Aquifoliaceae) and Prunus persicae (L.) Batsch (Rosaceae) 277 (Lanteri \& del Río, 2017a).

278

279 3-Naupactus marvaldiae Lanteri \& del Río, 2017

280 Geographic distribution. Northeastern Argentina (Misiones) and Southern Brazil (Santa 281 Catarina) (Lanteri \& del Río, 2017a).

282 
283

284

285

286

287 288

289

290

291

292

293

294

295

296

297

298

299

300

301

302

303

304

305

306

307

308

309

310

311

312

313

\section{4-Naupactus navicularis Boheman, 1840}

Geographic distribution. Northeastern Argentina (Misiones), Brazil (Minas Gerais, Paraná, Rio de Janeiro, Rio Grande do Sul, Santa Catarina and São Paulo) and Paraguay (Itapúa) (Lanteri \& del Rio, 2017a).

Host plants. Citrus sp, especially C. sinensis L. (Rutaceae) (Lanteri, Marvaldi \& Suárez, 2002).

\section{5-Naupactus xanthographus (Germar, 1824) (Figs. 1A-B)}

Geographic distribution. Argentina (Buenos Aires, Catamarca, Córdoba, Corrientes, Chaco, Entre Ríos, La Pampa, La Rioja, Mendoza, Misiones, San Juan, San Luis, Santa Fe, Santiago del Estero and Tucumán), southern Brazil (Rio Grande do Sul and Santa Catarina), Paraguay (Itapúa and Paraguarí), and Uruguay (Artigas, Colonia, Montevideo, Soriano and Treinta y Tres). It was introduced in Chile in 1942 (Durán, 1944) and is currently widespread from Atacama to Valparaiso and Juan Fernández Islands (Lanteri \& del Río, 2017a).

Host plants. Erythrina crista-galli L. (Fabaceae), Vitis vinifera L. (Vitaceae) and other fruit plants (Ripa, 1983; Elgueta, 1993; Lanteri \& del Río, 2017a).

\section{Naupactus rivulosus species group (Figs. 1C-E)}

It includes six species mainly distributed in the Chacoan biogeographic province: Naupactus argentinesis Hustache and N. bruchi (Heller) are endemic to Argentina; N. rivulosus (Olivier) and $N$. variegatus Hustache have been only recorded in the Parana forest of Argentina (Misiones) and are also widespread in Brazil and Paraguay; N. bridgesii Waterhouse mainly occurs in the Yungas of Argentina and Bolivia, and N. sulphurifer Pascoe in the Monte and Espinal biogeographic provinces. The latter species Naupactus sulphurifer (Fig. 1E) reaches the southernmost distribution of this group.

Other species probably belonging to the N. rivulosus species group are N. sahlbergi Boheman from Brazil (Federal District, Goiás, Minas Gerais and Paraná) and Naupactus peruvianus Hustache from the Yungas of Bolivia and Peru.

Description. Species large (female 17-22mm; male 14-16mm) (Figs. 1C-E). Integument strongly sclerotized. Scaly vestiture dull-colored and uniformly distributed or forming green, yellowish or pinkish stripes along pronotum and elytra and leaving denuded areas; scales round, small, 
314 slightly overlapped; elytral setae short, recumbent. Rostrum directed forward, 0.90-1.15X as long 315 as wide at apex; lateral carinae subparallel, blunt. Forehead 1.15-1.20X as wide as rostrum at 316 apex. Eyes convex. Antennae stout, medium length; scape clavate, usually not reaching hind 317 margin of eye; funicle article $2,2.5-3 \mathrm{X}$ as long as article 1; remaining funicle articles about $3 \mathrm{X}$ 318 as long as wide; club 2.5-3X as long as wide. Pronotum subconical, 1.10-1.30X as wide as long 319 (subcylindrical in N. sulphurifer); disc convex, usually slightly punctate; median sulcus usually 320 deep; posterolateral angles impressed; base bisinuate, beveled. Scutellum squamose, white.

321 Elytra 1.85-1.95X as long as wide; disc distinctly higher than pronotum in lateral view; humeri 322 very broad; base bisinuate; intervals convex; punctures usually large; subapical calli distinct. 323 Metathoracic wings usually well-developed. Procoxae lacking denticles; profemora wider than 324 metafemora, particularly in males; protibiae with large hook-like mucro and row of small 325 denticles on inner edge; meso and metatibiae lacking mucro in females, mesotibiae with small

326 327 328 329 330 331

332

333

334

335 336

337 338 Species included: 339 comb. Estero and Tucumán). mucro in males. Metatibial apex with large squamose corbel; dorsal comb about as long as distal

Female terminalia: sternite VIII suboval with or without apical prominence (Fig. 4A) or subrhomboidal (Fig. 4B); apodeme 2.5-3.5X as long as plate. Ovipositor (Fig. 5A) about 2/3 as long as of abdomen, with rows of long setae along posterior half, on external side of baculi. Spermatheca (Fig. 6A) subcylindrical, strongly sclerotized on proximal half (walls very thickened); collum very short, ramus indistinct to slightly developed. Spermathecal duct sclerotized, slender (narrower than opening of collum), about 3-6X as long as spermatheca. Male genitalia: apex of median lobe subacute with small prominence at the tip (Fig. 7A), slightly recurved; apodemes about as long as, to slightly shorter than median lobe (see Fig. 7F). Endophallus without sclerites.

\section{6-Naupactus argentinensis (Hustache, 1926)}

Geographic distribution. Endemic to Argentina (Catamarca, Misiones, Salta, Santiago del

Host plants. Gossypium hirsutum L. (Malvaceae) (Lanteri, Marvaldi \& Suárez, 2002).

7-Naupactus bridgesii Waterhouse, 1844 (= N. angulithorax Hustache, 1947). 
345 Geographic distribution. Argentina (Catamarca, Formosa, La Rioja, Misiones, Río Negro, 346 Salta, San Juan, San Luis and Tucumán) and Bolivia (Cochabamba, Potosí, Santa Cruz and 347 Sucre).

348 Host plants. Gossypium hirsutum L. (Malvaceae) and Medicago sativa L. (Fabaceae) (Lanteri, 349 Marvaldi \& Suárez, 2002).

350

351

8-Naupactus bruchi (Heller, 1921) (= Archopactus niveopectus Hustache, 1926).

352 Geographic distribution. Endemic to Argentina (Salta, Santiago del Estero and Tucumán).

353 Host plants. Prosopis kuntzei Harms Kuntze (Fabaceae) (Lanteri, Marvaldi \& Suárez, 2002).

354

355

9-Naupactus rivulosus (Olivier, 1790) (Figs. 1C-D)

356

Geographic distribution. Northeastern Argentina (Misiones), Brazil (Amazonas, Bahía,

357

Espirito Santo, Goiás, Mato Grosso do Sul, Minas Gerais, Paraná, Rio Grande do Sul, Rio de

Janeiro, Santa Catarina, and São Paulo), and Paraguay (Alto Paraná, Guairá, Itapúa, and 359 Paraguarí).

360

Host plants. Hibiscus sp (Malvaceae) (Bosq 1943), Gossypium hirsutum L. (Malvaceae), Vitis 361 vinifera L. (Vitaceae), Citrus sp. (Rutaceae) and Eucalyptus sp. (Myrtaceae) (Silva et al., 1968; Lanteri, Marvaldi \& Suárez, 2002; Lanteri, Guedes \& Parra, 2002).

363

364

10-Naupactus sulphurifer Pascoe, 1881 (Fig. 1E)

365

366

367

368

369

370

371

372

373 374

375

Geographic distribution. Argentina (Buenos Aires, Catamarca, Córdoba, La Rioja, Mendoza,

Misiones, Neuquén, Río Negro, Salta, San Luis, Santa Fe, Santiago del Estero and Tucumán) and Uruguay.

Host plants. Larrea divaricata Cav. and Larrea cuneifolia Cav. (Zygophyllaceae); Gossypium hirsutum L. and Sphaeralcea sp. (Malvaceae) (Lanteri, Marvaldi \& Suárez, 2002).

\section{1-Naupactus variegatus Hustache, 1938}

Geographic distribution. Argentina (Misiones), Brazil (Paraná and Rio Grande do Sul) and Paraguay. Argentina and Paraguay are new country records. 
376 It includes 15 species mainly occurring in the Parana and Atlantic forests of Brazil, only one

377 recorded in Argentina, $N$. delicatulus Hustache (Misiones). The remaining species are: $N$. ancora

378 Marshall, N. balteus Voss, N. barbicauda Boheman, N. chalybeipes Boheman, N. deses

379 Schoenherr, N. fuscus Boheman, N. leucographus Boheman, N. loripes (Germar), N. nubilosus

380 Boheman, N. ochreonotatus Voss, N. pulchellus Kuschel, N. submaculatus Hustache, $N$.

381 suturalis Boheman and $N$. wilsoni Boheman. Some of these names may be synonyms.

382

383 Description. Species medium-sized (female 12-20mm; male 11-16mm) (Figs. 1F-G).

384 Integument moderately sclerotized. Scaly vestiture very dense, brown or grey with cream of

385 whitish markings; scales round, broadly overlapped; elytral setae short, recumbent. Rostrum

386 directed forward, $1.15-1.30 \mathrm{X}$ as long as wide at apex; lateral carinae subparallel to slightly

387 convergent anteriad. Forehead 1.25-1.35X as wide as rostrum at apex. Eyes convex. Antennae

388 very slender, long; scape capitate, exceeding anterior margin of pronotum; funicular article 2, 2-

$3892.45 \mathrm{X}$ as long as funicular article 1, remaining articles 3-3.70X as long as wide; club 3.10-4.10X

390 as long as wide. Pronotum subconical, 1.15-1.35X as wide as long; disc flat to impressed,

391 smooth to slightly undulate; base bisinuate. Scutellum squamose. Elytra 1.50-1.90X as long as

392 wide, about as high as to slightly higher than pronotum in lateral view; humeri well-developed;

393 base bisinuate; intervals flat to slightly convex; punctures small, with a scale or seta on bottom;

394 subapical calli distinct only in females. Metathoracic wings well-developed. Legs long, slender;

395 procoxae without denticles; profemora slightly wider than metafemora; protibiae with sharp,

396 hook-like mucro and row of small denticles on inner margin; meso and metatibiae lacking mucro

397 and denticles in females; mesotibiae with small mucro in males. Metatibial apex with broad,

398 squamose corbel; dorsal comb longer than distal comb.

399 Female terminalia: sternite VIII subrhomboidal; apodeme about $2 \mathrm{X}$ as long as plate (see Fig.

400 4B). Ovipositor (see Fig. 5B) about 2/3 as long as abdomen, with rows of long setae along

401 posterior half, on external side of baculi (see Fig. 5B). Spermatheca (Fig. 6D) subcylindrical,

402 slightly sclerotized towards proximal end; collum conical, long; ramus distinct. Spermathecal

403 duct sclerotized, wide, curled, about 10X as long as spermatheca (Cyrtomon like, see Lanteri \&

404 del Rio, 2016). 
405 Male genitalia: apex of median lobe triangular (Fig. 7B), slightly recurved; apodemes about as 406 long as median lobe. Endophallus with sclerites consisted on a pyriform piece flanked by two 407 wing-like pieces (Cyrtomon-like, see Lanteri \& del Rio, 2016).

408

409 Species included:

410 12-Naupactus delicatulus Hustache, 1947 (Figs. 1F-G)

411 Geographic distribution. Northeastern Argentina (Misiones) and southern Brazil (Rio Grande 412 do Sul and Santa Catarina).

413

414

Naupactus auricinctus species group (Figs. 1H-I)

416 It includes about 20 species mainly distributed in the Atlantic and Parana forests of Brazil, three 417 of them occurring in northeastern Argentina, Bolivia and Paraguay. The species recorded in 418 Argentina are Naupactus auricinctus Boheman, N. condecoratus Boheman, and N. versatilis 419 Hustache, being the latter the most widespread in the country. The other species that belong to 420 this group are N. aerosus Boheman, N. agglomeratus Hustache, N aurolimbatus Boheman, $N$. 421 basalis Hustache, N. bipes (Germar), N. bondari Marshall, N. decorus (Fabricius), N. habenatus 422 Marshall, N. hypocrita (Germar), N. jacobi Hustache, N. macilentus Boheman, N. parallelus 423 Hustache, N. pedestris Voss, N. pithecius (Germar), N. proximus Voss, N. sanguinipes 424 Hustache, N. univittatus Boheman, N. viridicyaneus Hustache, N. viridisquamosus Boheman. 425 Some of these species names may be synonyms.

426

427 Description. Species medium-sized to large (females 9-17mm; males 8.5-12mm) (Figs. 1H-I). 428 Integument slightly sclerotized; antennae, tibiae, and meso and metafemora often reddish. Scaly 429 vestiture usually iridescent green, pinkish, copper-colored or grayish, in some species with 430 lighter stripes along sides of pronotum and elytra; scales round, slightly overlapped; elytral setae 431 fine, dark, erect, medium to very long. Rostrum directed forward, 1-1.30X as long as wide at 432 apex; lateral carinae subparallel, usually sharp. Forehead 1.25-1.45X as long as rostrum at apex. 433 Eyes usually convex. Antennae very slender, long; scape clavate to slightly capitate, usually 434 exceeding hind margin of eye (except in $N$. versatilis); funicular article 2, 2.3-3.4X as long as 435 article 1; remaining articles 3.35-4.7X as long as wide; club 3-3.5X as long as wide. Pronotum 
436 subcylindrical, often with remarkable sexual dimorphism, 1.20-1.35X as wide as long in females, 437 1.05-1.20X in males; disc slightly convex in females and strongly convex in males of some 438 species, granulose to strigose; base usually straight, not beveled. Scutellum setose. Elytra 1.6$4391.8 \mathrm{X}$ as long as wide, disc slightly higher than pronotum (females) or completely flat (males); 440 humeri broad to slightly reduced; base straight to slightly bisinuate, not beveled; intervals flat, 441 often with transversal rugosities; punctures small to indistinct; subapicall calli indistinct.

442 Metathoracic wings well-developed. Procoxae often with denticles in males; profemora much 443 wider than metafemora in males or some Brazilian species (N. condecoratus, N. bipes, $N$.

444 pithecius); protibiae often inwardly curved, with large mucro and row of usually small denticles 445 on inner margin; meso and metatibiae lacking mucro in females, and with small mucro in males. 446 Metatibial apex without corbels; dorsal comb about as long as distal comb.

447 Female terminalia: sternite VIII (see Fig. 4B) subrhomboidal; apodeme 2-3.5X as long as plate. 448 Ovipositor (see Fig. 5B) about $2 / 3$ as long as abdomen, with rows of long setae along posterior 449 half, on each side of baculi. Spermatheca (Fig. 6B) subcylindrical, strongly sclerotized towards 450 proximal half; collum and ramus indistinct. Spermathecal duct (Fig. 6B) sclerotized, slender, 451 usually spiraled.

452 Male genitalia: apex of median lobe subacute (see Fig. 7A), with or without distinct prominence 453 at the tip; apodemes shorter or about as long as median lobe. Endophallus without sclerites.

454

13-Naupactus auricinctus Boheman, 1833 (= N. ruficornis Boheman, 1840; N. chloris 456 Hustache, 1947) (Figs. 1H-I).

457 Geographic distribution. Argentina (Misiones), Bolivia (Santa Cruz), Brazil (Mato Grosso, 458 Mato Grosso do Sul, Minas Gerais, Paraná, Rio de Janeiro, Rio Grande do Sul, Santa Catarina 459 and São Paulo) and Paraguay (Central, Cordillera, Guairá, Itapúa and Paraguarí).

460 Host plants. Ilex paraguariensis Saint Hill. (Aquifoliaceae) (Bosq 1943) and Gossypium 461 hirsutum L. (Malvaceae) in Argentina; P̈̈nus elliottii Engelm. and Pinus taeda L. (Pinaceae); and 462 Casearia sylvestris Sw. (Salicaceae) in Brazil.

463

464 14-Naupactus condecoratus Boheman, 1840 (= N. bosqi Hustache, 1947).

465 Geographic distribution. Argentina (Corrientes and Misiones), Brazil (Paraná, Rio de Janeiro, 466 Santa Catarina, and São Paulo) and Paraguay. 
467 Host plants. Ilex paraguariensis Saint Hill. (Aquifoliaceae) (Lanteri, Marvaldi \& Suárez, 2002).

468

469

470

471

472

473

474

475

476

477

478

479

480

481

482

483

484

485

486

487

488

489

490

491

492

493

494

495

496

497
15-Naupactus versatilis Hustache 1947 (= N. imbellis Hustache, 1947)

Geographic distribution. Argentina (Corrientes, Chaco, Entre Ríos, Misiones, Santiago del Estero, Salta and Tucumán), Brazil (Goiás, Minas Gerais, Paraná, Rio de Janeiro, Santa Catarina and Sāo Paulo) and Paraguay (Guairá and Itapúa).

Host plants. Citrus sp. (Rutaceae) (Lanteri, Guedes \& Parra, 2002). 
498 bisinuate, beveled. Scutellum squamose or setose. Elytra 1.55-1.95X as long as wide, distinctly 499 higher than pronotum in lateral view; humeri very broad; base bisinuate; intervals usually flat; 500 punctures small; subapical calli slight. Metathoracic wings well-developed. Procoxae lacking 501 denticles; profemora usually slightly wider than metafemora; protibiae with small acute mucro 502 (large in N. viridicinctus) and row of small denticles on inner margin; meso and metatibiae 503 lacking mucro and denticles. Metatibial apex lacking corbel (slender and setose in N. cyphoides); 504 dorsal comb about as long as distal comb.

505 Female terminalia: sternite VIII suboval (see Fig. 4A), subpentagonal (Fig. 4D) or subromboidal 506 (see Fig. 4B); apodeme about 3.25-4X as long as plate. Ovipositor (see Fig. 5B) about 2/3 as 507 long as abdomen, with rows of long setae along posterior half, on external side of baculi. 508 Spermatheca usually subcylindrical (see Fig. 6A) (subglobose in N. cyphoides (Fig. 6E)) and 509 strongly sclerotized towards proximal end (walls very thickened); collum indistinct; ramus 510 indistinct to slightly developed. Spermathecal duct slightly sclerotized, usually more slender than 511 opening of collum, short (1-3X as long as spermatheca).

512 Male genitalia: apex of median lobe subacute, curved, with small prominence at the tip (see Fig. 513 7A); apodemes about as long as, to slightly longer than median lobe. Endophallus without 514 sclerites.

515

516 Species included:

517 16-Naupactus cyphoides (Heller, 1921) (Fig. 2C) (= N. griseomaculatus (Hustache, 1923); N. 518 prasinus Hustache, 1947; N. viridimarginalis Hustache, 1947; N. calamuchitanensis Hustache, 519 1947; N. viridinitens Hustache, 1947; N. viridulus Hustache, 1947).

520 Geographic distribution. Argentina (Buenos Aires, Catamarca, Córdoba, Corrientes, Chaco, 521 Chubut, Formosa, Misiones, La Rioja, Rio Negro, Salta, San Luis, Santa Fe, Santiago del Estero 522 and Tucumán), Bolivia (Tarija and Santa Cruz), Paraguay (Alto Paraguay, Central and 523 Presidente Hayes) and Uruguay (Rio Negro).

524 Host plants. Prosopis kutzei Harms Kuntze, Prosopis nigra (Grisebach) Hieron, Medicago 525 sativa L. (Fabaceae); Schinopsis balansae Engl. (Anarcadiaceae) (Lanteri, Marvaldi \& Suárez, 526 2002).

527 
529 Geographic distribution. Endemic to northwestern Argentina (Jujuy, Salta, Santiago del Estero 530 and Tucumán).

531 Host plants. Prosopis kutzei Harms Kuntze, Prosopis nigra (Grisebach) Hieron, Medicago 532 sativa L. (Fabaceae); Schinopsis quebracho-colorado (Griseb.) Engl. (Anarcadiaceae) (Lanteri, 533 Marvaldi \& Suárez, 2002).

534

535

18-Naupactus laticollis Hustache, 1947

536 Geographic distribution. Endemic to northwestern Argentina (Salta and Santiago del Estero).

537 Host plants. Prosopis nigra (Grisebach) Hieron (Fabaceae) (Lanteri, Marvaldi \& Suárez, 2002). 538

539

540

541

542

543

544

545

546

547

548

549

550

551

552

553

554

555

556

557

558

559

\section{9-Naupactus schapleri Hustache, 1947}

Geographic distribution. Argentina (Formosa and Tucumán), Brazil (Mato Grosso, Mato

Grosso do Sul and São Paulo) and Paraguay (Capital district and Itapúa). Brazil is a new country record.

20-Naupactus tarsalis Boheman, 1840 (Figs. 2A-B) (=N. glaucivittatus Blanchard, 1847; N. albidiventris Hustache, 1947)

Geographic distribution. Argentina (Chaco, Corrientes, Formosa, Misiones, Salta, Santiago del Estero and Tucumán), Bolivia (Beni, Santa Cruz and Tarija), Brazil (Bahia, Federal District, Maranhão, Mato Grosso, Mato Grosso do Sul, Minas Gerais, Pará, Pernambuco, Rio Grande do Norte, Rio de Janeiro, São Paulo and Tocantins) and Paraguay (Amambay, Concepción and Paraguarí).

Host plants. Citrus sp (Rutaceae) (Lanteri, Guedes \& Parra, 2002)

\section{1-Naupactus viridicinctus (Fig. 2D) Boheman, 1833}

Geographic distribution. Argentina (Misiones) and Brazil (Minas Gerais, Santa Catarina and São Paulo). Naupactus cinereidorsum species group (Figs. 2E-F)

It includes five Argentinean species mainly distributed in the Chacoan biogeographic province, none of them endemic to the country. Naupactus cinereidorsum Hustache is the most widespread 
560 in Argentina and follows the arch of the Espinal; N. castaneus Hustache and N. denudatus

561 Hustache range in Chaco and Yungas; $N$. argentatus Hustache is mainly distributed in Chaco,

562 and $N$. virens Boheman is the only restricted to the northeast (Parana forest) and widespread in

563 Brazil (Parana forest and Cerrado). Other species probably belonging to this group are $N$.

564 latifrons Boheman, N. morio Boheman, N. pictus Boheman, from Brazil, and N. praedatus

565 Erichson, from Peru.

566

567 Description. Species medium-sized (female 11-14mm; male 9-11 mm) (Figs. 2E-F). Integument 568 strongly sclerotized. Scaly vestiture grey, pale green or pale brown, lacking stripes of different 569 colors or almost denuded of scales on dorsum; scales round, slightly overlapped or lacking; 570 elytral setae short, recumbent. Rostrum slightly directed forward, $0.85-1.10 \mathrm{X}$ as long as wide at 571 apex; lateral carinae slightly convergent towards apex, blunt. Forehead 1.20-1.45X as wide as 572 rostrum at apex. Eyes convex. Antennae moderately stout, medium length; scape clavate, not 573 reaching to slightly exceeding hind margin of eye; funicular article 2, 2-2.35X as long as 574 funicular article 1, remaining articles $2-3.8 \mathrm{X}$ as long as wide; club $2.85-4.10 \mathrm{X}$ as long as wide. 575 Pronotum subcylindrical to slightly subconical, 1.20-1.50X as wide as long; disc flat, smooth to 576 slightly granulose; base slightly bisinuate, beveled. Scutellum squamose. Elytra 1.50-1.90X as

577 long as wide, slightly higher than pronotum in lateral view; humeri broad; base slightly

578 bisinuate; intervals usually flat; punctures usually large; subapical calli indistinct. Metathoracic

579 wings usually well-developed. Procoxae without denticles; profemora slightly wider than

580 metafemora; protibiae with mucro and row of denticles on inner margin; meso and meta tibiae

581 lacking mucro and denticles in females; metatibiae with small mucro in males. Metatibial apex

582 without corbel; dorsal comb about as long as distal comb.

583 Female terminalia: sternite VIII subcircular (Fig. 4E) or subrhomboidal (see Fig. 4B); apodeme 584 about 2-4X as long as plate (the shortest apodemes are recorded for $N$. virens and $N$. argentatus). 585 Ovipositor (see Fig. 5A) $1 / 2$ to $3 / 4 \mathrm{X}$ as long as abdomen, with rows of long fine setae along 586 posterior half, on external side of baculi (more sparse and slender in short ovipositors).

587 Spermatheca (see Fig. 6A) usually subcylindrical and strongly sclerotized towards proximal end 588 (subglobose en $N$. denudatus, see Fig. 6E); collum very short; ramus usually indistinct.

589 Spermathecal duct slightly sclerotized, slender (about same width of opening of collum), not 590 spiralized, usually short (2-3X as long as spermatheca). 
591 Male genitalia: apex of median lobe acute to subacute, with small prominence at the tip (see Fig.

592 7A); apodemes about as long as median lobe. Endophallus without sclerites.

593

594 Species included:

595 22-Naupactus argentatus Hustache, 1947

596 Geographic distribution. Argentina (Corrientes, Misiones, Santa Fe and Santiago del Estero)

597 and Paraguay (Presidente Hayes). Paraguay is a new country record.

598 Host plants. Saccharum officinarum L. (Poaceae).

599

600 23-Naupactus castaneus Hustache, 1947

601 Geographic distribution. Argentina (Chaco and Misiones), Bolivia (Santa Cruz) and Brazil

602 (Mato Grosso do Sul). Brazil is a new country record.

603

604 24-Naupactus cinereidorsum Hustache, 1947 (Figs. 2E-F)

605 Geographic distribution. Argentina (Buenos Aires, Chaco, Córdoba, Entre Ríos, Misiones,

606 Santa Fe, Santiago del Estero, and Tucumán) and Uruguay (Montevideo).

607 Host plants: Medicago sativa L. and Glycine max (L.) Merr. (Fabaceae), Heliantus annuus L.

608 (Asteraceae) (Lanteri, Marvaldi \& Suárez, 2002).

609

610 25-Naupactus denudatus Hustache, 1947

611 Geographic distribution. Argentina (Catamarca, Jujuy, Salta and Santiago del Estero) and

612 Bolivia (Tarija).

613

614 26-Naupactus virens Boheman, 1840

615 Geographic distribution. Northeastern Argentina (Misiones), Brazil (Federal District, Mato

616 Grosso, Mato Grosso do Sul, Minas Gerais, Paraná, Rio de Janeiro, Rondonia and São Paulo)

617 and Paraguay (Presidente Hayes). Paraguay is a new country record.

618

619

Naupactus hirtellus (Voss) species group (Figs. 3A-B) 
620 It includes one species distributed in the Chacoan biogeography province of Argentina and

621 Paraguay, Naupactus hirtellus, and two species from the Yungas of Bolivia and Peru (N. lizeri

622 Hustache and N. viridimicans Hustache).

623

624 Description. Species medium sized (females 12-14.5mm; males 9-11mm) (Figs. 3A-B).

625 Integument slightly sclerotized. Scaly vestiture dense, iridescent green or opaque grey, except

626 the usually denuded elytral suture; scales round to oval; elytral setae medium length, erect.

627 Rostrum slightly directed forward (gular angle almost $90^{\circ}$ ), 1-1.15X as long as wide at apex;

628 lateral carinae subparallel to slightly convergent anteriad, blunt. Forehead 1.350-1.50X as wide

629 as rostrum at apex. Eyes convex. Antennae slender, medium length; scape clavate, reaching to

630 slightly exceeding hind margin of eye; funicular article 2, 2.25-2.50X as long as funicular article

631 1; remaining articles 2.85-3X as long as wide; club oval, 3-3.6X as long as wide. Pronotum

632 subcylindrical to slightly subconical, with slightly curved flanks, 1.15-1.35X as wide as long;

633 disc flat, smooth to slightly granulose; base straight to slightly bisinuate. Scutellum squamose or

634 setose. Elytra 1.50-1.65X as long as wide, slightly higher than pronotum in lateral view; humeri

635 well-developed to slightly reduced, rounded; base straight to slightly bisinuate, not beveled;

636 intervals flat; punctures usually indistinct; apical calli indistinct. Metathoracic wings usually

637 well-developed. Procoxae without denticles; profemora slightly wider than metafemora;

638 protibiae with small mucro and lacking row of denticles on inner margin; meso and metatibiae

639 lacking mucro and denticles. Metatibial apex with narrow setose corbel; dorsal comb about as

640 long as distal comb.

641 Female terminalia: sternite VIII subrhomboidal (Fig. 4C); apodeme 3-4X as long as plate.

642 Ovipositor (see Fig. 5B) as long as abdomen, with rows of long setae along posterior half, on

643 external side of baculi. Spermatheca subcylindrical (see Fig. 6A), moderately sclerotized; collum

644 and ramus indistinct. Spermathecal duct sclerotized, very slender, about 5X as long as

645 spermatheca.

646 Male genitalia: apex of median lobe (Fig. 7C) very elongate, rounded, strongly recurved (Fig.

647 7E); apodemes slightly shorter than median lobe. Endophallus without sclerites.

648

649 Species included:

650 27-Naupactus hirtellus (Voss, 1932) (=N. cupreata (Voss, 1932); N. caroli Hustache, 1947) 
651 Geographic distribution. Argentina (Chaco, Jujuy, Formosa, Misiones and Salta) and Paraguay 652 (Central, Concepción, Cordillera, Guairá and Paraguarí).

653 Host plants. Gossypium hirsutum L. (Malvaceae) in Paraguay.

654

655

Naupactus leucoloma species group (Fig. 3C)

656 It was revised by Lanteri \& Marvaldi (1995) and includes five species mainly distributed in the

657 Pampean biogeographic province and nearby areas (Chaco, Yungas, Espinal and borders of the

658 Paraná forest). Naupactus leucoloma Boheman shows the broadest distribution (Guzmán, Lanteri

659 \& Confalonieri, 2012), being introduced in Chile (including Eastern Island and Juan Fernández

660 Islands) and other countries worldwide. Naupactus minor (Buchanan) and N. peregrinus

661 (Buchanan) are typical Pampean species and were also introduced outside their native range.

662 Naupactus albolateralis Hustache is endemic to Argentina (Chacoan biogeographic province)

663 and N. tucumanensis Hustache ranges also in Bolivia (Yungas) and Paraguay (Chaco).

664

665 Species included:

666 28-N. albolateralis Hustache, 1947

667 Geographic distribution. Endemic to Argentina (Santiago del Estero).

668

669

29-Naupactus leucoloma Boheman, 1840 (= N. dubius (Buchanan, 1942), N. fecundus

670 (Buchanan, 1947), N. imitator (Buchanan, 1947), N. pilosus (Buchanan, 1942), N. striatus

671 (Buchanan, 1942).

672 Geographic distribution. Species broadly distributed in Argentina (Buenos Aires, Catamarca,

673 Chaco, Chubut, Córdoba, Corrientes, Chubut, Entre Ríos, Formosa, Jujuy, La Pampa, La Rioja,

674 Mendoza, Río Negro, Salta, San Juan, San Luis, Santa Fe, Santiago del Estero, and Tucumán),

675 southern Brazil (Rio Grande do Sul) and Uruguay (Artigas, Canelones, Cerro Largo, Colonia,

676 Durazno, Lavalleja, Montevideo, Paysandú, Soriano and Tacuarembó). Introduced in Chile,

677 Peru, Mexico, Australia, New Zealand, South Africa and USA.

678 Host Plants. There are about 385 known hosts for this species, including ornamentals, fruit trees, 679 horticultural and industrial crops, and forage. According to Kuschel (1972, 1990) it shows 680 preferences for legumes, particularly Phaseolus vulgaris (Fabaceae). In Argentina the main hosts 681 of economic importance are alfalfa (Medicago sativa L.) and soybean (Glycine max L. (Merr.) 
682 (Fabaceae), strawberry (Fragaria sp) and Prunus avium L. (Rosaceae), onion (Allium cepa L.) 683 (Amarydillaceae), potatoes (Solanum tuberosum L.) and pepper (Capsicum annuum L.) 684 (Solanaceae) (Lanteri, Marvaldi \& Suárez, 2002; Lanteri et al., 2013). Solidago chilensis Meyen 685 and Wedelia glauca (Ort.) Hoff. (Asteraceae) are common wild host plants.

686

687 30-Naupactus minor (Buchanan, 1947) (=N. breviscapus Hustache, 1947)

688 Geographic distribution. Argentina (Buenos Aires, Santa Fe and Entre Ríos), southern Brazil 689 (Rio Grande do Sul) and Uruguay (Canelones, Montevideo, Rivera). Introduced in USA.

690 Host Plants. It is harmful for alfalfa (Medicago sativa L.), Lotus spp. and soybean (Glycine max 691 L. (Merr.)) in Argentina, Brazil and Uruguay (Lanteri, Marvaldi \& Suárez, 2002; Lanteri et al., 692 2013).

693

694

695 Geographic distribution. Argentina (Chaco, Entre Ríos, Misiones, Santa Fe), southern Brazil

31-Naupactus peregrinus (Buchanan, 1939) (= N. brevicrinitus Hustache, 1947).

696 (Rio Grande do Sul), Paraguay (Central) and Uruguay (Paysandú). Introduced in USA and 697 Azores Islands.

698 Host Plants. It is harmful for alfalfa (Medicago sativa L.) and soybean (Glycine max L. (Merr.)) 699 in Argentina, Brazil and Uruguay (Lanteri, Marvaldi \& Suárez, 2002; Lanteri et al., 2013). In 700 Paraguay is associated with cotton, Gossypium hirsutum (Malvaceae).

701

702 32-N. tucumanensis Hustache, 1947 (Fig. 3C)

703 Geographic distribution. Argentina (Buenos Aires, Catamarca, Córdoba, Chaco, Formosa, 704 Salta, Santiago del Estero and Tucumán), Bolivia (Santa Cruz) and Paraguay (Itapúa).

705 Host Plants. Medicago sativa L. (Fabaceae) (Lanteri, Marvaldi \& Suárez, 2002), Zea mays L. 706 (Poaceae) and Schinopsis balansae Engl. (Anarcadiaceae).

707

708

Naupactus purpureoviolaceus species group (Figs. 3D-I)

709 It includes five species mainly distributed in the Pampean biogeographic province. Naupactus

710 rugosus Hustache and $N$. verecundus Hustache are endemic to Argentina (the latter was 711 introduced in Chile) and mainly occur in Espinal and Monte provinces; N. chordinus Boheman 712 and $N$. dives (Klug) are typical Pampean species and $N$. purpureoviolaceus Hustache is broadly 
713 distributed in northeastern areas of Argentina, southern Brazil, Paraguay and Uruguay (Pampean, 714 Chacoan and edges of Parana forest).

715 Other species that probably belong to this group are Naupactus alternevittatus Hustache, $N$. 716 pilipes Hustache and N. termolerasi Hustache, from Uruguay and southern Brazil.

717

718 Description. Species medium-sized to large (females 11-19mm; males 9-17mm) (Figs. 3D-I). 719 Integument moderately to strongly sclerotized. Scaly vestiture usually sparse, iridescent green, 720 purple, or copper-colored, dull-colored or completely lacking on dorsal surface (N. rugosus); 721 elytral setae short and recumbent or long and erect. Rostrum slightly directed forward (gular 722 angle almost $90^{\circ}$ ), 1.10-1.20X as long as wide at apex; lateral carinae subparallel, very sharp 723 (convergent anteriad and blunt in N. rugosus). Forehead 1.30-1.40X as wide as rostrum at apex. 724 Eyes usually convex. Antennae stout, short to medium length; scape clavate, not reaching hind 725 margin of eye; funicular article 2, 1.30-1.90X as long as funicular article 1; remaining articles 2$7262.4 \mathrm{X}$ as long as wide; club $2.50-3.25 \mathrm{X}$ as long as wide. Pronotum subcylindrical, 1.25-1.45X as 727 wide as long, with slightly curved and slightly granulose, or with strongly curved flanks and 728 granulose; base straight, slightly beveled. Scutellum setose (squamose in N. rugosus). Elytra $7291.45-170 \mathrm{X}$ as long as wide, higher than pronotum in lateral view; humeri reduced, rounded; base 730 straight; intervals flat or slightly convex; punctures small; apical calli indistinct. Metathoracic 731 wing reduced. Procoxae without denticles; profemora slightly wider than metafemora; protibiae 732 with small to medium sized mucro and row of denticles on inner margin; meso and metatibiae 733 usually lacking mucro and denticles (mesotibiae with mucro and denticles in males of $N$. 734 rugosus). Metatibial apex without corbel; dorsal comb about as long as, to slightly shorter than 735 distal comb.

736 Female terminalia: sternite VIII usually subrhomboidal (see Fig. 4B) (suboval with prominence 737 at the tip in N. rugosus, Fig. 4F); apodeme usually $2.5-4 \mathrm{X}$ as long as plate (about $1.5 \mathrm{X}$ in $N$. 738 rugosus). Ovipositor usually half length of abdomen, with rows of long and often coarse setae 739 along posterior half, on external side of baculi (Fig. 5B-C) (setae indistinct in N. dives and $N$. 740 rugosus Figs. 5D-E); coxites strongly sclerotized and styli lacking only in N. dives (Fig. 5D).

741 Spermatheca (Fig. 6C) subcylindrical, strongly sclerotized on proximal half; collum and ramus 742 indistinct. Spermathecal duct (Fig. 6C) usually slender, undulate and of variable length (1.5-4X 743 as long as spermatheca). 
744 Male genitalia: apex of median lobe usually subacute with small prominence at the tip (see Fig.

745 7A) (with broad prominence in $N$. dives); apodemes slightly shorter to about half length of

746 median lobe (Fig. 7F). Endophallus without sclerites or with small U-shaped sclerites.

747

748 Species included:

749 33-Naupactus chordinus Boheman, 1833 (Figs. 3F-G) (= N. suffitus Boheman, 1833; N.

750 fernandezi Hustache, 1947; N. sericellus Hustache, 1947; N. sericeus Hustache, 1947).

751 Geographic distribution. Argentina (Buenos Aires, Chubut, Misiones and Santiago del Estero)

752 and Uruguay (Canelones, Cerro Largo, Montevideo and San José).

753 Host plants. Glycine max L. (Merr.) (Fabaceae), in Buenos Aires province.

754

755 34-Naupactus dives Klug, 1829 (= N. klugii Boheman, 1833)

756 Geographic distribution. Argentina (Buenos Aires), Brazil (Rio Grande do Sul and Santa 757 Catarina) and Uruguay (Lavalleja, Maldonado and San José).

758 Host plants. Eryngium sp (Apiaceae), a perennial plant introduced from Europe and currently 759 extended in the Pampean biogeographic province.

760

761

35-Naupactus purpureoviolaceus Hustache, 1947 (Figs. 3D-E) (=N. persimilis (Hustache, 762 1947))

763 Geographic distribution. Argentina (Buenos Aires, Chaco, Córdoba, Corrientes, Entre Ríos, 764 Misiones, Santa Fe and Tucumán), Brazil (Río Grande do Sul), Paraguay (Alto Paraná, 765 Caaguazí, Central, Cordillera, Itapúa, Paraguarí and San Pedro) and Uruguay (Artigas, Cerro 766 Largo, Maldonado, Paysandú, Rivera, and Treinta y Tres). Brazil is a new country record.

767 Host plants. Gossypium hirsutum L. (Malvaceae) in Paraguay; Phaseolus sp. and Glycine max 768 L. (Merr.) (Fabaceae), in southern Brazil.

769

770 36-Naupactus rugosus Hustache, 1947 (Figs. 3H-I)

771 Geographic distribution. Endemic to central-western Argentina (Catamarca, La Pampa,

772 Mendoza, San Luis and Santiago del Estero). 
773 Host plants. Eupatorium sp., Senecio subulatus D. Don ex Hook. \& Arn. and Grindelia 774 chiloensis (Cornel) Cabrera (Asteraceae); Larrea divaricata Cav and Larrea nitida Cav. 775 (Zygophyllaceae) (Lanteri, Marvaldi \& Suárez, 2002).

776

777 37-Naupactus verecundus Hustache, 1947 (= N. calamuchitanus Hustache, 1947; N. vianai 778 Hustache, 1947)

779 Geographic distribution. Endemic to Argentina (Buenos Aires, Catamarca, Córdoba, 780 Corrientes, Chubut, La Pampa, La Rioja, Mendoza, Neuquén, Río Negro, San Luis, Santiago del 781 Estero and Tucumán) and introduced in Chile. Silva et al. (1968) cited this species for southern 782 Brazil, associated with grapes, however, we could not confirm the presence of $N$. verecundus in 783 this country.

784 Host plants. Baccharis salicifolia (Ruiz et Pavón) Pers., Baccharis spartioides (Hook. et Arn.) 785 Remy. (Asteraceae) and Portieria sp (Zygophyllaceae). It is harmful for Vitis vinifera L. 786 (Vitaceae), other fruit plants and ornamental garden shrubs in Argentina (Mendoza province) and 787 central Chile (Elgueta 1993; Lanteri, Marvaldi \& Suárez, 2002).

788

789

790

DISCUSSION AND CONCLUSIONS

791 We recognized nine species groups of Naupactus showing different biogeographic patterns 792 which are consistent with the results of a track analysis reported by del Río, Morrone \& Lanteri 793 (2015). The Naupactus xanthographus, N. delicatulus and N. auricinctus species groups mainly 794 occur in the Atlantic and Parana forests of Brazil, and most of the Argentinean species are only

795 recorded in the northeast of the country (Misiones province). The Naupactus hirtellus, $N$.

796 cinereidorsum, $N$. rivulosus and $N$. tarsalis species groups have the highest species diversity in 797 the Chacoan biogeographic province, with some of them also being present in neighboring

798 biogeographic provinces (Yungas, Espinal, Pampa, Parana forest, and Cerrado in Brazil). The 799 Naupactus leucoloma and N. purpureoviolaceus species groups are mainly distributed in the 800 Pampean biogeographic province, and also occur in nearby areas, e.g. Chaco, Espinal, and 801 Monte. Some species of these groups reach the southernmost distribution limit of the genus 802 Naupactus in the Americas, and exhibit morphological characters typical of treeless and/ or 803 xerophilous environments, e.g. reduction of hind wings, a strongly sclerotized integument almost 
804 denuded of scales, presence of long erect setae on the elytra, and presence of rows of denticles 805 along the inner edge of all tibiae. In all Naupactus groups, the most differentiated species occur 806 at the edges of their geographic distributions, where the environmental conditions are usually 807 more extreme e.g. N. rugosus in the Monte biogeographic province; N. suphurifer mainly in 808 Monte and Espinal, and N. dives in Espinal and arid areas of the Pampean biogeographic 809 province

810

811

812

813

814

815

816

817

818

819

820

821

822

823

824

825

826

827

828

829

830

831

832

833

Some species groups are more homogeneous than others in terms of external morphology and/or characters of genitalia. The species included in the group of $N$. rivulosus (type species of Naupactus) share quite uniform ovipositors and spermathecae, e.g. ovipositor about $2 / 3$ as long as the abdomen, with rows of setae along the posterior half and well-developed styli (del Río et al., 2018) (Fig. 5A), and spermatheca with strongly sclerotized walls, a very short collum (duct lobe) and a slightly developed ramus (gland lobe) (Fig. 6A). The sternite VIII varies in shape, being oval with or without apical prominence, or subrhomboidal as in most Naupactini (Lanteri \& del Río, 2017b) (see Figs. 4 A-B, F), and usually bears a long apodeme. Naupactus sulphurifer (Fig. 1E) has a female terminalia typical of the $N$. rivulosus species group but differs in some characters of external morphology, e.g. a subcylindrical and slightly granulose pronotum instead of a subconical and smooth pronotum as in most species of the group, slightly longer antennae than those of the remaining species, and all tibiae having rows of denticles on the inner edge, at least in males.

Naupactus cyphoides is the most different within the N. tarsalis species group (Fig. 2C), showing shorter antennae than the remaining species (the funicle article 2 is less than 2 times as long as the funicle article 1 and the funicle articles 3-7 are less than 2 times as long as wide at apex); a pronotum more than 1.50 times as wide as long; a metatibial apex with a very slender corbel; and a broader spermatheca without thickened walls (Fig. 7E). The spermatheca of the single Argentinean species of the $N$. delicatulus species group does not show the typical generic characters, e.g., it has a subcylindrical and very long collum, a well-developed ramus (see Fig. 6D) and a broad and curled spermathecal duct resembling that of the species of Cyrtomon Schoenherr (Lanteri \& del Río, 2016). A spermatheca of similar shape is observed in $N$. dissimulator and N. marvaldiae, both belonging to the same subgroup within the $N$. xanthographus species group. 
834 The $N$. auricinctus species group is quite homogeneous in terms of external morphology and 835 genitalia and differs from the other groups by the presence of a spiraled spermathecal duct (Fig. 836 6B). Based on a phylogenetic analysis by del Río et al. (2018), this species group may be related 837 to the N. purpureoviolaceus species group, which is characterized by having a usually undulate 838 spermathecal duct (Fig. 6C). Two species of the latter group exhibit ovipositor characters that 839 differ from those of most Naupactus. In $N$. dives, the ovipositor is distinguished by lacking long 840 setae on its posterior half, by having more sclerotized coxites as compared to the remaining 841 species and by lacking styli (Fig. 5D); while N. rugosus has a short and wide ovipositor without 842 the typical rows of long setae (Fig. 5E). The ovipositor of $N$. dives resembles that of Floresianus 843 Hustache, Eurymetopus Schoenherr and Priocyphus Hustache, all of which seem to be adapted

844 for laying eggs into the soil (Lanteri \& del Río, 2008); and the ovipositor of N. rugosus

845 resembles that of Trichonaupactus densior Hustache, both of which inhabit similar environments 846 (Lanteri \& del Rio, 2008; Lanteri \& del Rio, 2016).

847 The sternite VIII of N. rugosus looks like that of some species within the $N$. rivulosus species 848 group (e.g. N. bruchi), but it has a shorter apodeme (Fig. 4F). Moreover, in N. rugosus the 849 integument is more strongly sclerotized, the scaly vestiture is almost lacking, the pronotum is 850 more rugose and all the tibiae have rows of denticles on the inner edge, particularly in males. 851 Likewise, other Naupactini from environments that are also dominated by xerophilous trees and 852 thorny shrubs (i.e. Enoplopactus Heller, Priocyphopsis Hustache, Mendozella Hustache) have 853 denticles on all tibiae and often display tubercles on pronotum and elytra (Lanteri, 1990; Lanteri 854 \& del Río, 2016).

855 The morphology of the male genitalia provides few useful characters for the differentiation of 856 species groups of Naupactus. In most species, the apex of the median lobe is subacute and ends 857 in a narrow or broad prominence (Figs. 7E-F). In the N. leucoloma and N. purpureoviolaceus 858 species groups, this prominence may be indistinct and the apodemes are usually much shorter 859 than the median lobe (Fig. 7F), whereas in most of the remaining groups the latter are usually 860 about as long as the median lobe (Fig. 7E). The arrow-shaped (Fig. 7D) or subtriangular (Fig. 861 7B) apex, recorded for some members of the $N$. xanthographus species group ( $N$.

862 xanthographus, $N$. dissimilis and $N$. mimicus) and $N$. delicatulus, respectively, are not typical of 863 Naupactus. In addition, only N. delicatulus and two species of the N. xanthographus species 864 group ( $N$. dissimulator and N. marvaldiae) have distinct sclerites in the endophallus, which 
865 consist of a pyriform piece flanked by two wing-like pieces (Cyrtomon-like, see Lanteri \& del 866 Rio, 2017b); this feature correlates with a spermatheca of different shape (i.e. with a long 867 subcylindrical collum).

868 A phylogenetic analysis by del Río et al. (2018), suggests that the $N$. leucoloma species group is 869 probably monophyletic and closely related to the $N$. purpureoviolaceus and N. auricinctus 870 species groups; the $N$. tarsalis species group (represented by $N$. cyphoides) may be close to the

$871 N$. cinereidorsum species group; and the two subgroups of the N. xanthographus species group 872 do not form a clade. Even if future studies reveal that some species groups of Naupactus herein 873 described are not natural, we believe that their recognition is useful in facilitating species

874 identification, and in testing phylogenetic hypotheses in a historical biogeographic context (see 875 del Río, Morrone \& Lanteri, 2015; del Rio et al., 2018).

876

877 ACKNOWLEDGEMENTS

878 Thanks are due to all the curators for loaning material and helping us with the collections, to 879 Bruno Pianzola for taking the photographs, to Paulina Hernandez for technical assistance and to 880 Silvia Pietrovsky for English revision of the manuscript.

881

882

883

884

885

886

887

888

889

890

891

892

893

894

\section{REFERENCES}

Alonso-Zarazaga MA, Lyal CHC . 1999. A world catalogue of families and genera of Curculionoidea: (Insecta: Coleoptera) excepting Scolytidae and Platypodidae. Barcelona: Entomopraxis, D.C.P.

Bordón C. 1997. El género Naupactus Dejean (Coleoptera: Curculionidae) en Venezuela. Acta Biologica Venezuelica 17: 11-51.

Buchanan LLF. 1939. The species of Pantomorus of America north of Mexico. U.S. Department of Agriculture Miscellaneus Publication 341: 1-39.

Cabrera, AL \& Willink A. (1973) Biogeografía de América Latina. Serie de Biología, Monografía 13. Secretaría de la OEA, Washington D.C.

del Río MG, Lanteri AA, Guedes JVC. 2006. Taxonomic revision and cladistic analysis of Teratopactus Heller (Coleoptera, Curculionidae). Invertebrate Systematic 20(5): 585-602. 
895 del Río MG, Morrone JJ, Lanteri AA. 2015. Evolutionary biogeography of South American 896 weevils of the tribe Naupactini (Coleoptera: Curculionidae). Jornal of Biogeography 42:

897

898

899

900

901

902

903

904

905

906

907

908

909

910

911

912

913

914

915

916

917

918

919

920

921

922

923

924

925 1293-1304.

del Río MG, Lanteri AA. New synonymies, new combinations and designation of lectotypes in weevils of the tribe Naupactini (Coleoptera: Curculionidae: Entiminae). Zootaxa, In press.

del Río MG, Rodriguero MS, Confalonieri VA, Lanteri AA. 2018. Molecular and Morphological Phylogenetic Analysis of Naupactus Dejean (Curculionidae: Entiminae) and Allied Genera: The Dilemma of Classification. Diversity 10: 59 DOI: 10.3390/d10030059.

Elgueta M. 1993. Las especies de Curculionoidea (Insecta: Coleoptera) de interés agrícola en Chile. Museo Nacional de Historia Natural. Publicación Ocasional (Santiago) 48(1): 1-79 Gómez CA, Lanteri AA. 2006. Primer registro de Naupactus ruizi Coleoptera: Curculionoidea) asociado con Pinus ponderosa (Gymnospermae: Pinaceae) en Patagonia. Revista de la Sociedad Entomológica Argentina 65(1-2) : 107-109.

Guedes CJ, Lanteri AA, Parra JRP. 2005. Chave de Identificação, Ocorrência e Distribuição dos Curculionídeos-das-raízes dos Citros em São Paulo e Minas Gerais. Neotropical Entomology 34(4): 577-584.

Guzmán NV, Lanteri AA, Confalonieri VA. 2012. Colonization ability of two invasive weevils with different reproductive modes. Evolutionary Ecology 26(6): 1371-1390.

Hustache A. 1923. Curculionides de l'exploration Lizer-Delétang au Chaco bolivien. Anales de la Sociedad Cientifica Argentina 96: 278-300.

Hustache A. 1926. Contribution à l'étude des Curculionidea de la République Argentine (première note). Anales del Museo Nacional de Historia NaturalBernardino Rivadavia 34: $155-261$.

Hustache A. 1938. Curculionides nouveaux de I'Amérique méridionale, qui se trouvent dans le Deutsches Entomologisches Institut ( $2^{\circ}$ note). Arbeiten über morphologische und taxonomische Entomologie aus Berlin-Dahlem 5(3): 265-288.

Hustache A. 1947. Naupactini de I'Argentine et des régions limitrophes (Col. Curculion.). Revista de la Sociedad Entomológica Argentina 13(1-5): 3-146.

Lanteri AA. 1986. Revisión del género Asynonychus Crotch (Coleoptera: Curculionidae). Revista de la Asociación de Ciencias Naturales del Litoral 17(2): 161-174. 
926 Lanteri A.A. 1990. Revisión sistemática y análisis filogenético de las especies del género

927 Enoplopactus Heller 1921 (Coleoptera: Curculionidae). Boletín de la Sociedad Biológica de 928 Concepción 61: 71-92.

929

930 Lanteri AA. 1995. Análisis cladístico y evolución de la partenogénesis en el grupo de Pantomorus 931

932 auripes (Coleoptera: Curculionidae). Revista de la Sociedad Entomológica Argentina

933 54(1-4): 17-24.

Lanteri AA, Loiácono MS. 1990. Systematic study of the Pantomorus viridisquamosus species 934 group (Coleoptera: Curculionidae). Insecta Mundi 4(1-4): 1-10.

935

Lanteri AA, O’Brien CW. 1990. Taxonomic revision and cladistic analysis of Atrichonotus

936

937

938

939

940

941

942

943

944

945

946

947

948

949

950

951

952

953

954

955

956
Buchanan (Coleoptera: Curculionidae). Transactions of the American Entomological Society 116: 697-725.

Lanteri AA, Marvaldi AE. 1995. Graphognathus Buchanan, a new synonym of Naupactus Dejean, and systematics of the N. leucoloma species group (Coleoptera: Curculionidae). The Coleoptist Bulletin 49: 206-228.

Lanteri AA, Loiácono MS, Coscarón MC, Díaz NB. 1991(90). Estudio sistemático del grupo de especies afines a Pantomorus auripes Hustache (Coleoptera: Curculionidae). Revista de la Sociedad Entomológica Argentina 49(1-4): 3-16.

Lanteri AA, Marvaldi AE, Suárez SM. 2002. Gorgojos de la Argentina y sus plantas huéspedes. Tomo 1: Apionidae y Curculionidae. Tucumán: Sociedad Entomológica Argentina.

Lanteri AA, Guedes JCV, Parra JRP. 2002. Weevil Injurious for Roots of Citrus in São Paulo State, Brazil. Neotropical Entomology 31(4): 561-569.

Lanteri AA, del Río MG. 2008. Caracteres genitales de la hembra en la clasificación y filogenia de la tribu Naupactini (Coleoptera: Curculionidae). In: Llorente Bousquets J, Lanteri AA, eds. Contribuciones taxonómicas en órdenes de insectos hiperdiversos. Distrito Federal: UNAM- RIBES-CYTED, 159-176.

Lanteri AA, Bigolin M, del Rio MG, Guedes JVC. 2013. On the presence of six species of Naupactini damaging soybean in Brazil. Neotropical Entomology 42: 325-327.

Lanteri AA, del Río MG. 2016. Taxonomy and cladistics of the group of genera related to Cyrtomon Schöenherr (Coleoptera: Curculionidae: Naupactini). Revista de la Sociedad Entomológica Argentina 75(1-2): 55-77. 
957 Lanteri AA, del Río MG. 2017a. Naupactus xanthographus (Germar) species group

958

959

960

961

962

963

964

965

966

967

968

969

970

971

972

973

974

975

976

977

978

979

980

981

982

983

984

985

986

987

(Curculionidae: Entiminae: Naupactini): a comprehensive taxonomic treatment. Journal of Natural History 51: 1557-1587.

Lanteri AA, del Río MG. 2017b Phylogeny of the tribe Naupactini (Coleoptera: Curculionidae) based on morphological characters. Systematic Entomology 42: 429-447 DOI: 10.1111/syen.12223.

Morrone JJ. 1999. The species of Entiminae ranged in America south of the United States. Anales del Instituto de Biología de la UNAM, Serie Zoología 70: 99-168.

Morrone JJ, Lanteri AA. 1991(90). Ubicación sistemática y variación intraespecífica de Pantomorus ruizi (Bréthes) (Coleoptera: Curculionidae). Revista de la Sociedad Entomológica Argentina 49(1-4): 17-26.

O'Brien CW, Wibmer GJ. 1982. Annotated checklist of the weevils (Curculionidae sensu lato) of North America, Central America and the West Indies (Coleoptera: Curculionoidea). Memoirs of the American Entomological Institute 34: 1-382.

Ripa R. 1983 El burrito de los frutales y vides Naupactus xanthographus. Biología y control. INIA Boletín divulgativo (Chile) 98: 1-29.

Scataglini MA, Lanteri AA, Confalonieri VA. 2005. Phylogeny of the Pantomorus-Naupactus Complex based on morphological and molecular data (Coleoptera: Curculionidae). Cladistics 21: 131-142.

Schoenherr CJ . 1833. Genera et species curculionidum, cum synonymia hujus family. Vol. 1. Paris: Roret.

Schoenherr CJ. 1840. Genera et species curculionidum, cum synonymia hujus family. Vol. 6. Paris: Roret.

Silva AGd'A, Gonçalves CR, Monteiro Galvão D, Gonçalves AJL, Gomes J, do Nacimento Silva M, de Simoni L. 1968. Quarto Catálogo dos insetos que vivem nas plantas do Brasil, seus parasitos e predadores. Río de Janeiro: Ministerio da Agricultura, Dep. de Defesa e Inspecão Agropecuaria, Serviço de Defesa Sanitaria Vegetal, Laboratorio Central de Patología Vegetal.

Wibmer GJ, O'Brien CW. 1986. Annotated checklist of the weevils (Curculionidae sensu lato) of South America (Coleoptera: Curculionoidea). Memoirs of the American Entomological Institute 39: 1-563. 
988

989

990 


\section{Figure 1}

Habitus photographs of Naupactus xanthographus, N. rivulosus and $N$. auricinctus species groups, dorsal views.

(A) Naupactus xanthographus, female. (B) N. xanthographus, male. (C) N. rivulosus, female.

(D) N. rivulosus, male. (E) N. sulphurifer, female. (F) N. delicatulus, female. (G) N. delicatulus, male. (H) N. auricinctus, female. (I) N. auricinctus, male. Credits: Bruno Pianzola. 


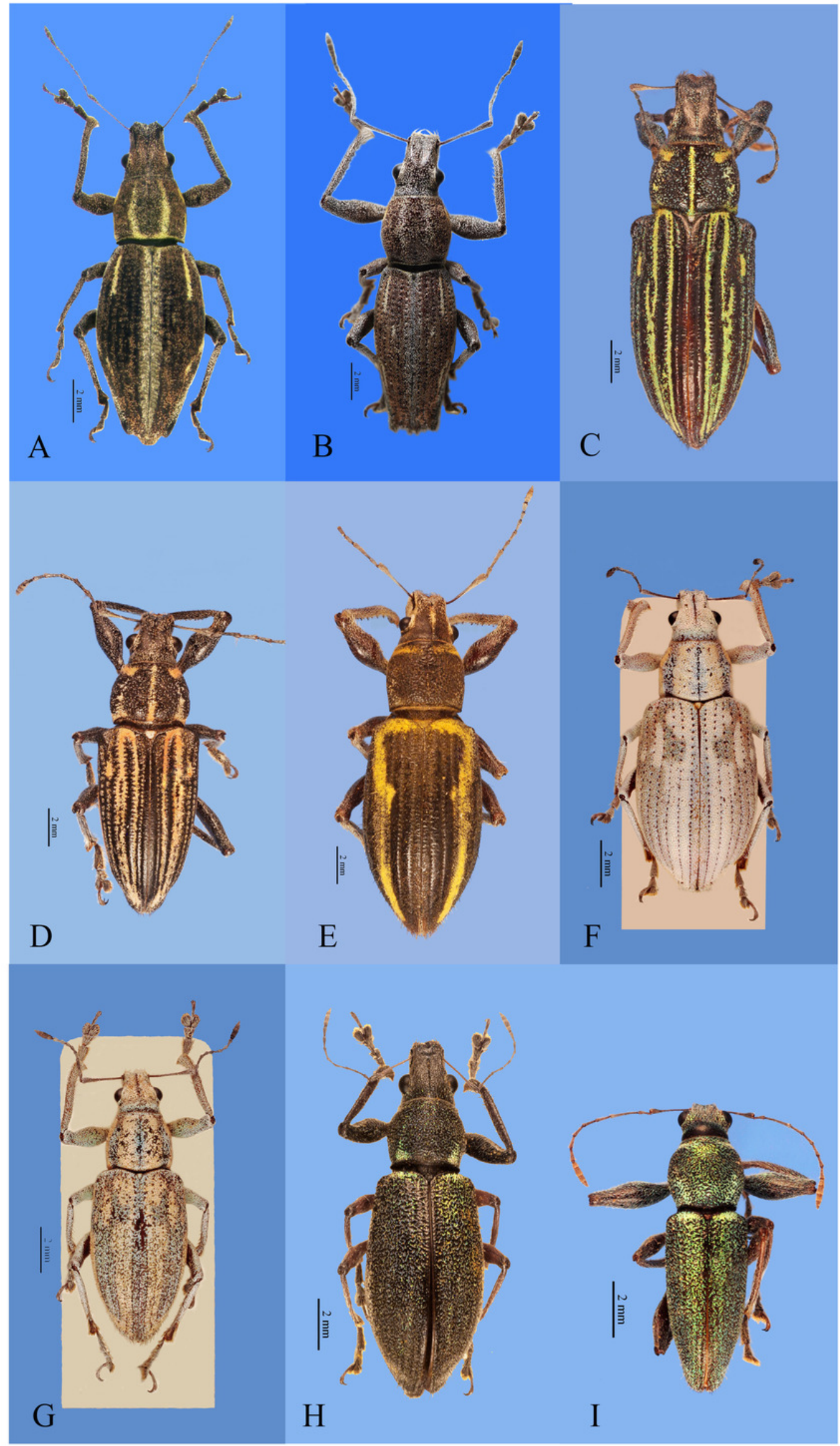


Figure 2

Habitus photographs of Naupactus tarsalis and $N$. cinereidorsum species groups, dorsal views.

(A) Naupactus tarsalis, female. (B) N. tarsalis, male. (C) N. cyphoides, female. (D) N.

viridicinctus, female. (E) N. cinereidorsum, female. (F) N. cinereidorsum, male. Credits: Bruno Pianzola. 


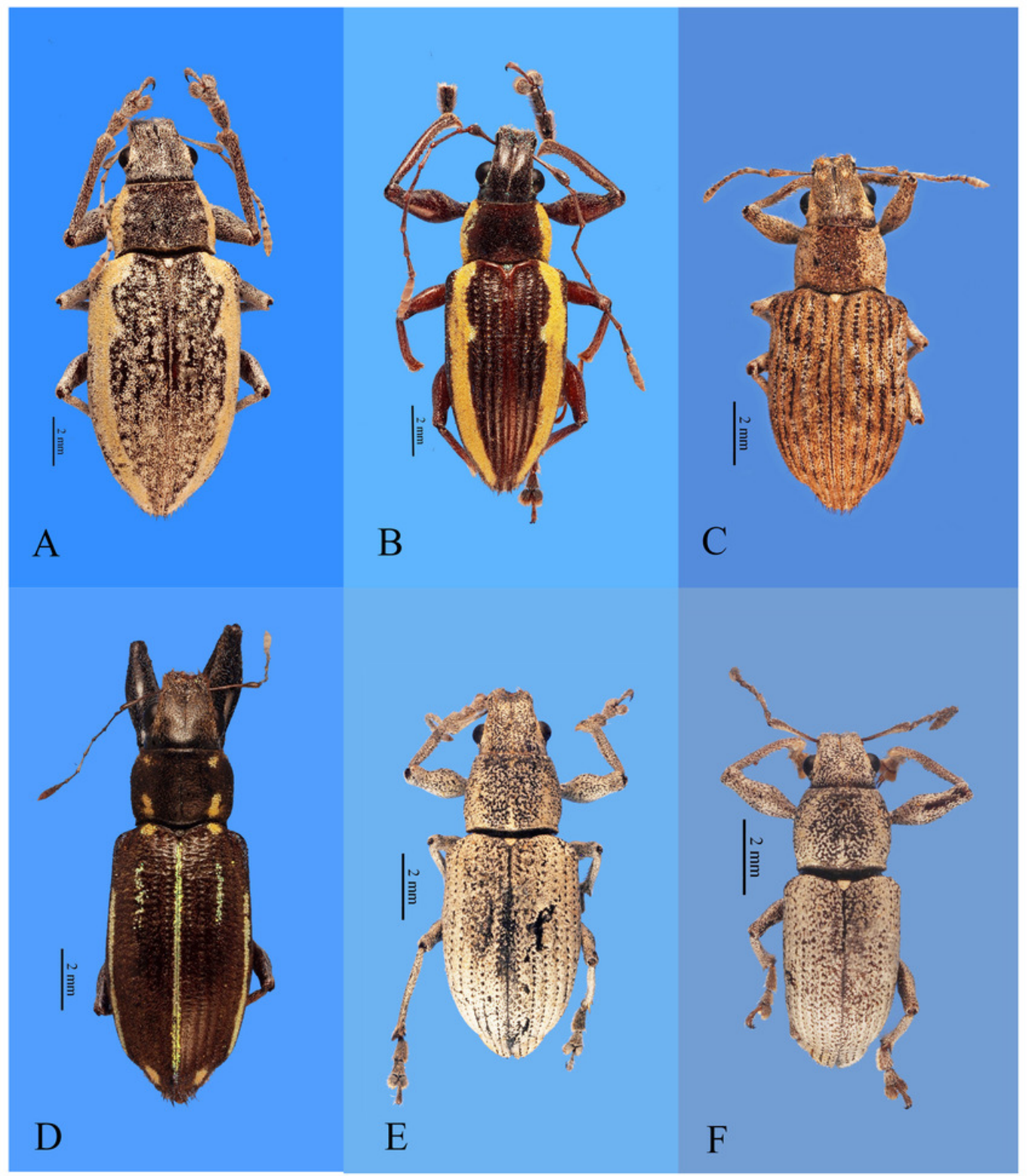




\section{Figure 3}

Habitus photographs of Naupactus hirtellus, N. leucoloma and N. purpureoviolaceus species groups, dorsal views.

(A) Naupactus hirtellus, female. (B) Naupactus hirtellus, male. (C) N. tucumanensis, female.

(D) N. purpureoviolaceus, female. (E) N. purpureoviolaceus, male. (F) N. chordinus, female.

(G) N. chordinus, male. (H) N. rugosus, female. (I) N. rugosus, male. Credits: Bruno Pianzola. 


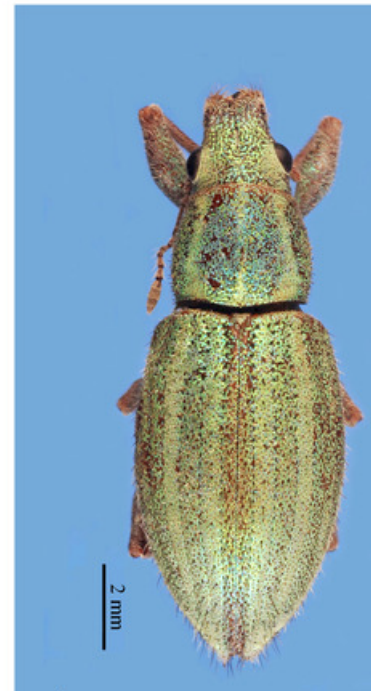

A

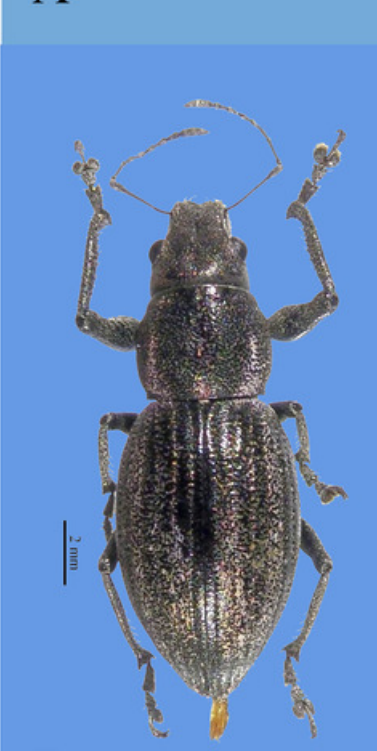

$\mathrm{D}$

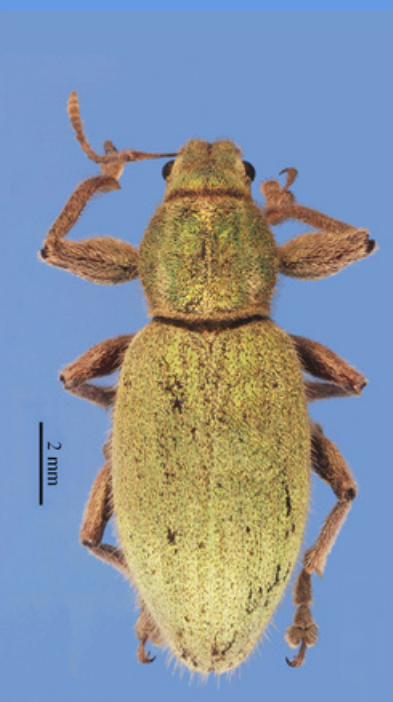

G

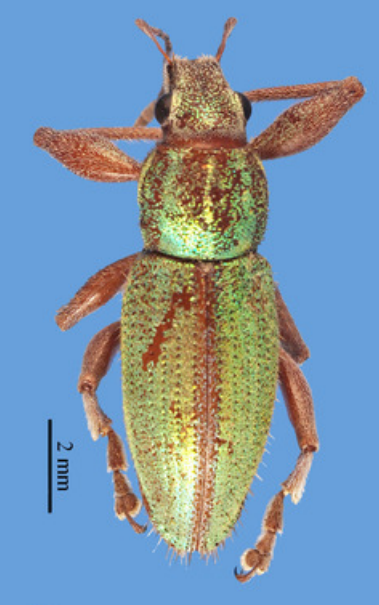

B
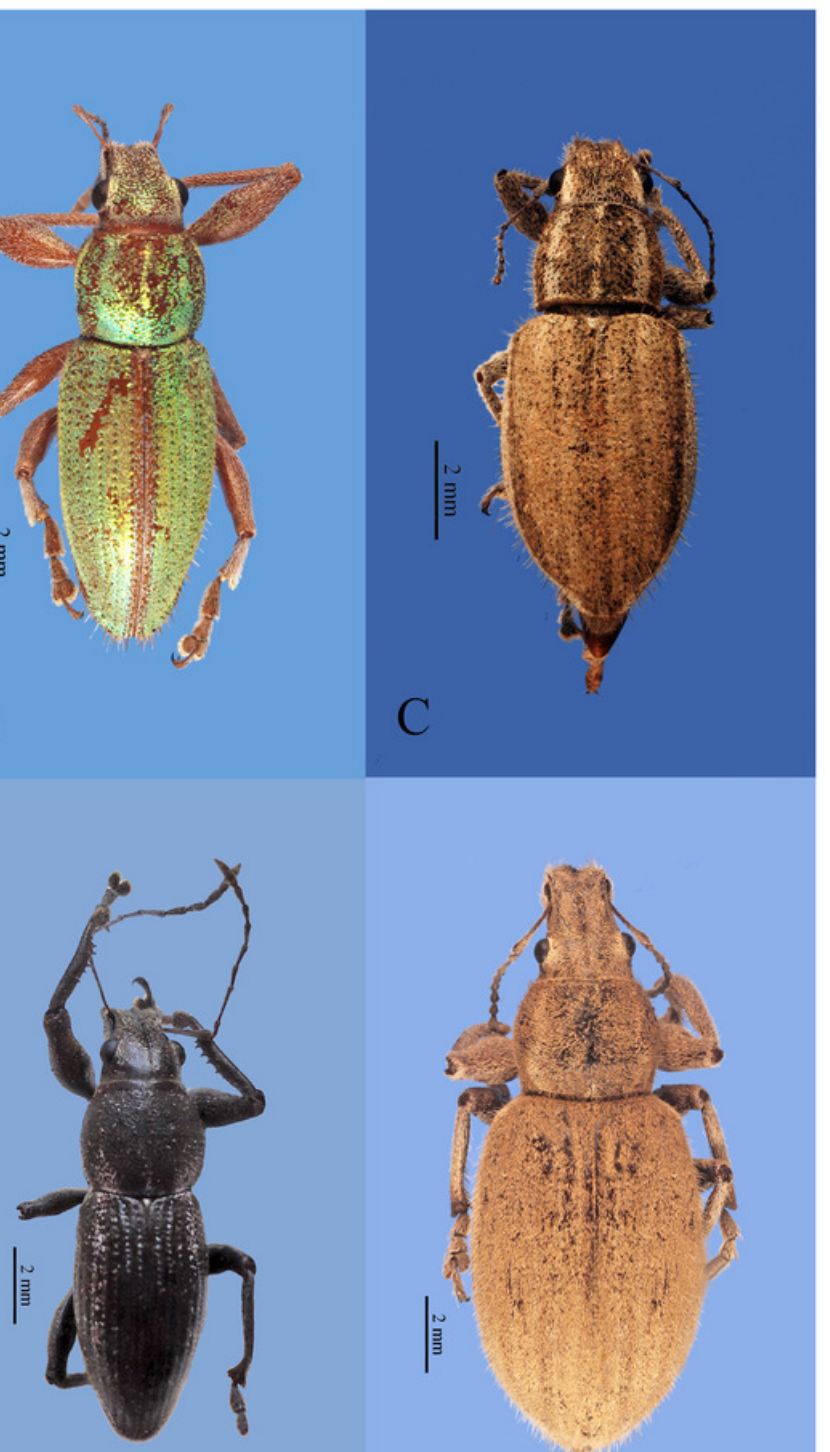

E

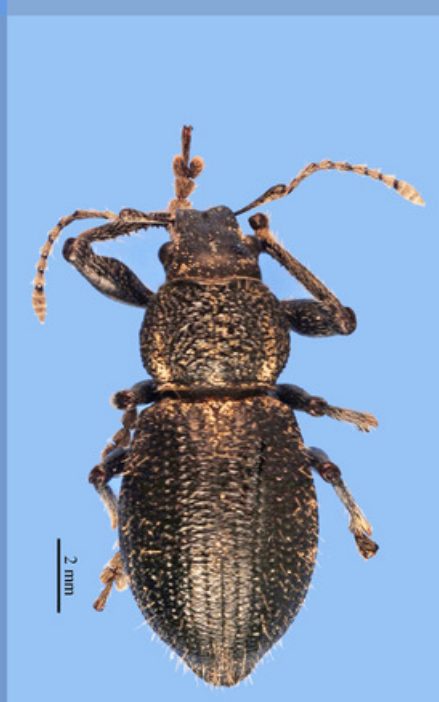

$\mathrm{H}$

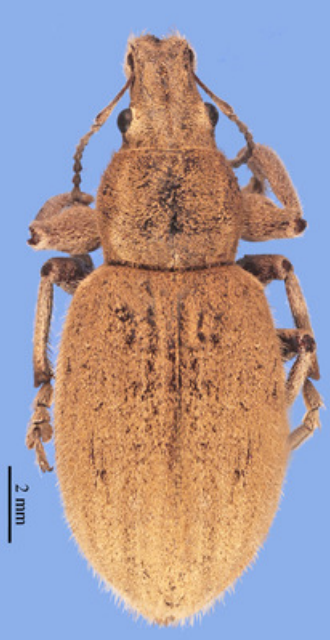

F

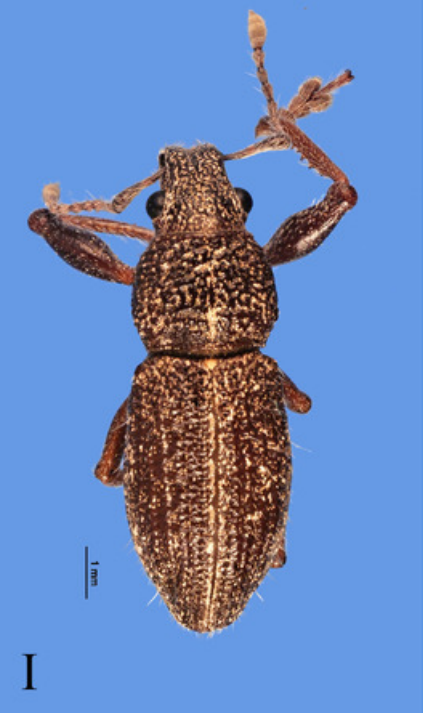




\section{Figure 4}

Female terminalia, sternite VIII.

(A) Naupactus rivulosus, suboval plate, (B) N. argentinensis, subrhomboidal plate. (C) N. hirtellus, subrhomboidal plate. (D) N. tarsalis, subpentagonal plate. (E) N. denudatus, subcircular plate. (F) N. rugosus, suboval plate with acute apex. 


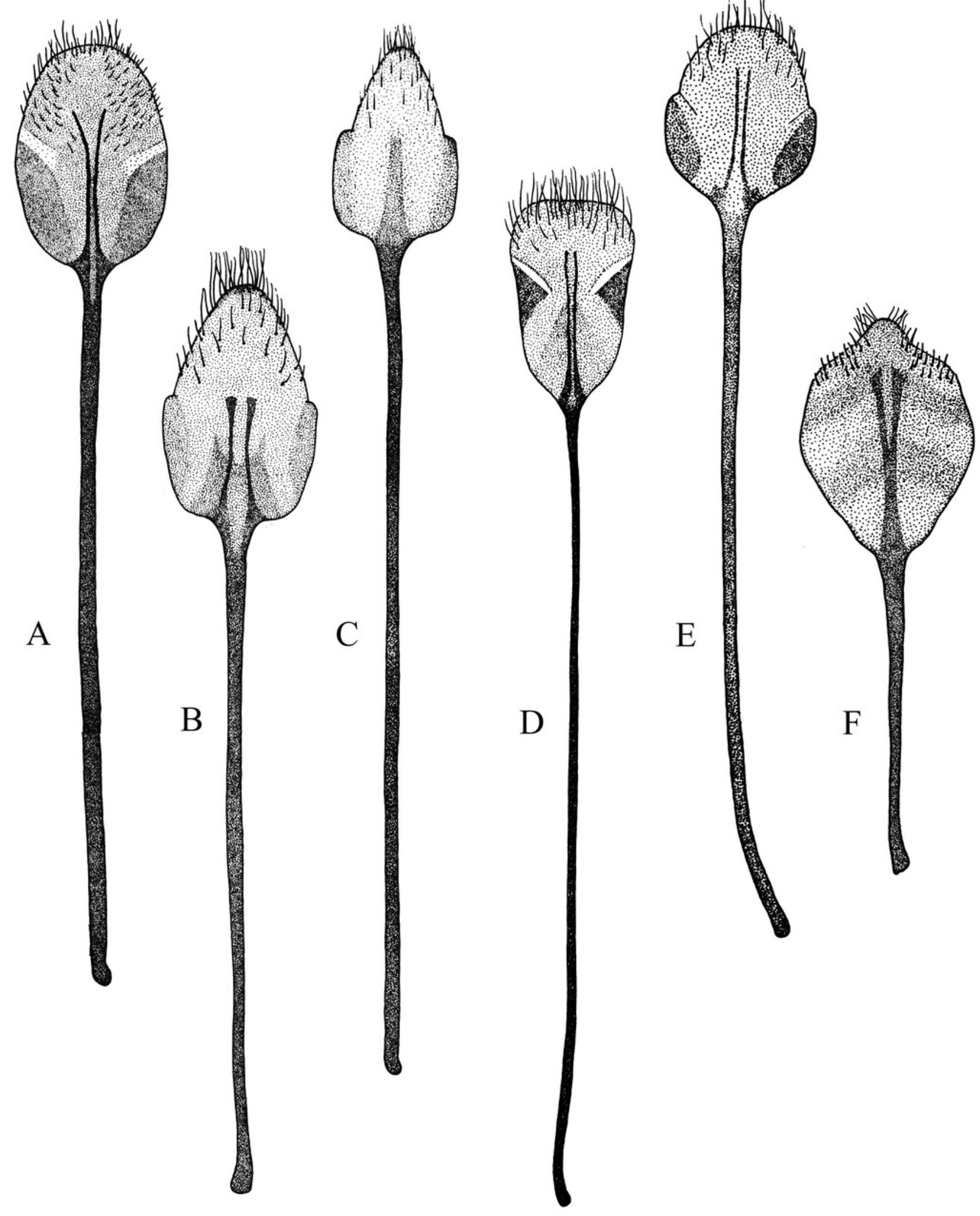


Figure 5

Female genitalia, ovipositor, ventral views.

(A) Naupactus argentinensis, long, with rows of setae. (B) N. chordinus, long, with rows of setae. (C) N.verecundus moderately long, with rows of broad setae. (D) N. dives, moderately long, lacking setae and styli. (E) N. rugosus, short, lacking setae.
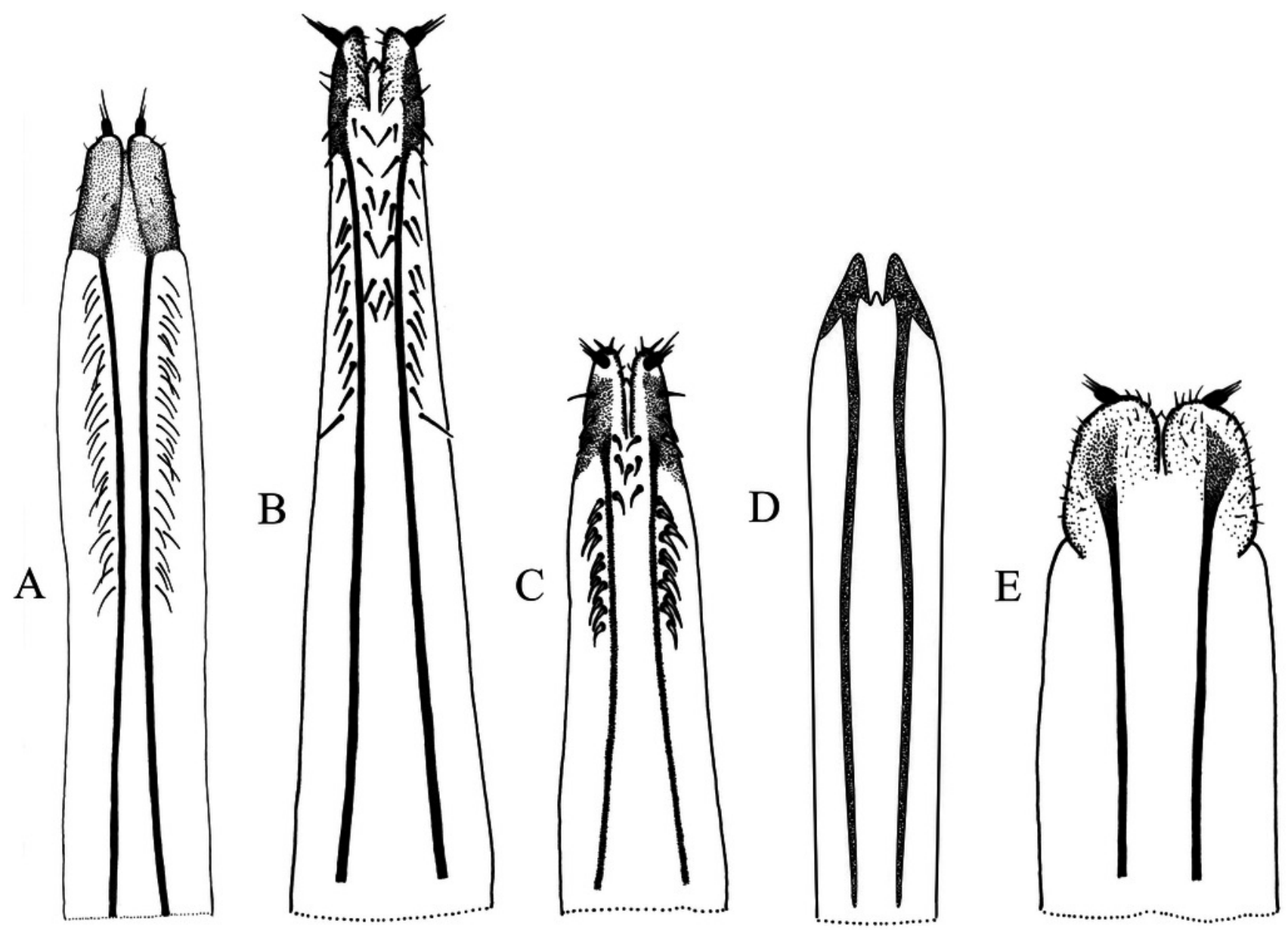
Figure 6

Female genitalia, spermathecae.

(A) Naupactus sulphurifer, subcylindrical. (B) N. auricinctus, subcylindrical, duct spiraled. (C) $N$. verecundus subcylindrical, duct undulate. (D) N. dissimulator, subcylindrical with long collum . (E) N. cyphoides, subglobose.
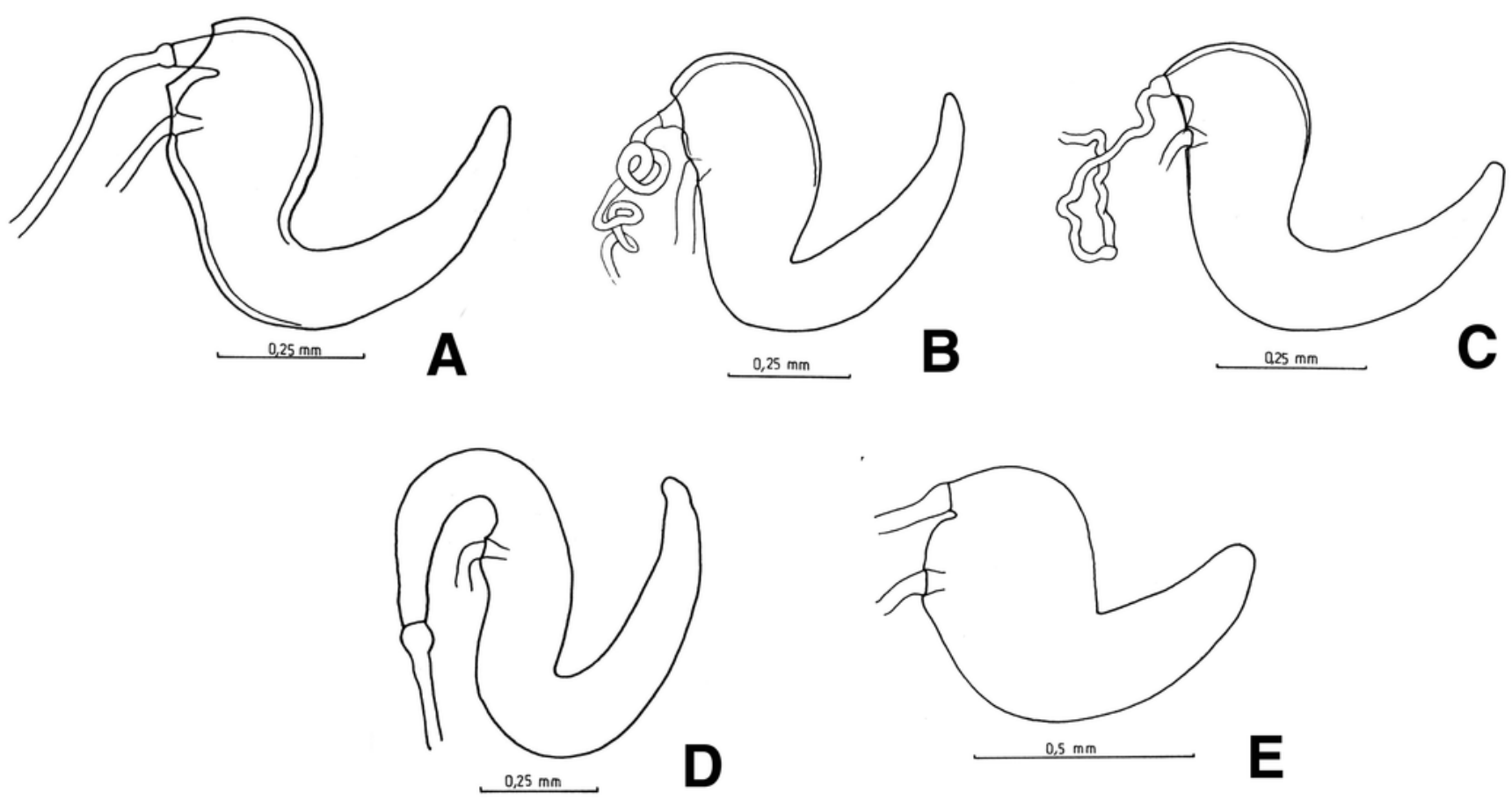
Figure 7

Male genitalia, median lobe.

(A-D) apex of median lobe, ventral views. (E-F) median lobe, lateral views. (A) Naupactus sulphurifer, subacute with prominence at the tip. (B) N. delicatulus, subtriangular. (C) N. hirtellus, rounded. (D) N. xanthographus, arrow-shaped. (E) N. hirtellus, apex strongly recurved. (F) N. chordinus, apex slightly recurved.
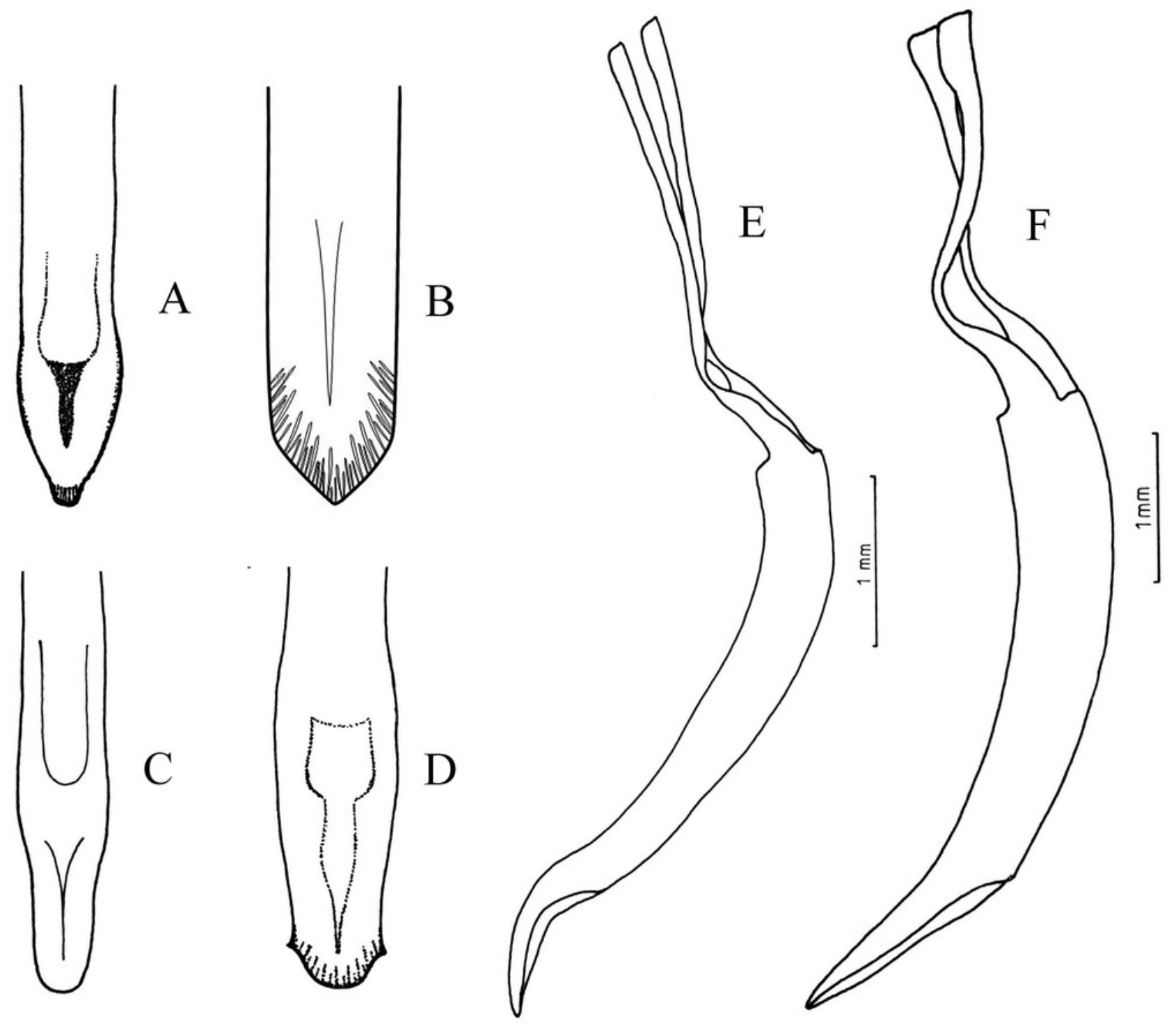